This BOOK may be kept out TWO WEEKS ONLY, and is subject to a fine of FIVE CENTS a day thereafter. It was taken out on the day indicated below: 



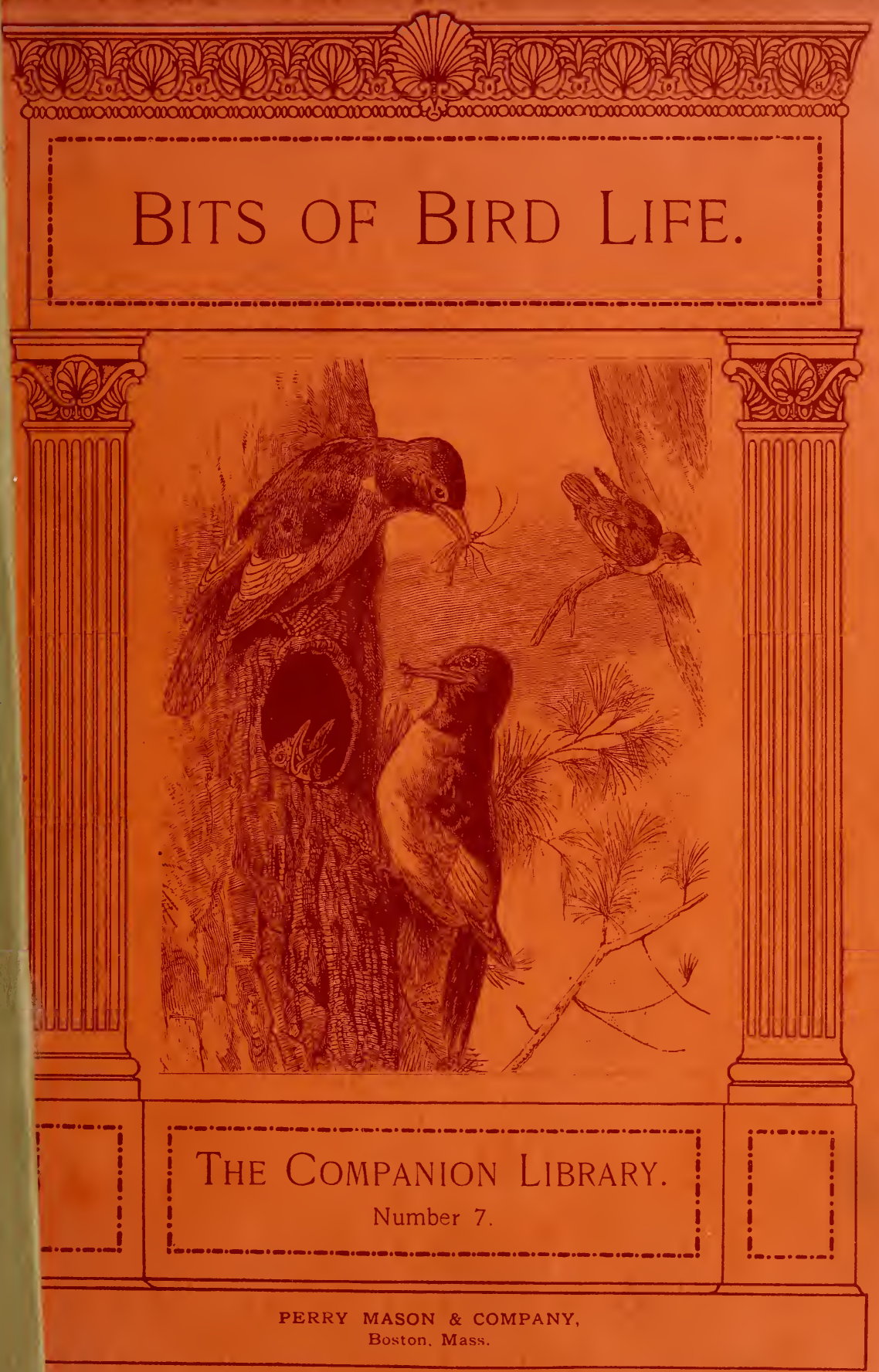




\section{THE COMPANION LIBRARY}

Is a collection of stories, travel-sketches and descriptive articles, complete, exact, and so interesting as to meet the need of all who want "a book for the leisure hour." It is made up from the works of some of the best writers for The Youth's Companion.

The Library comprises the following volumes, each containing sixtyfour pages, illustrated and bound uniform with this book:

No. I. A Book of Stories: Patriotism, Bravery and Kindness.

No. 2. Glimpses of Europe: Travel and Description.

No. 3. The American Tropics: Mexico to the Equator. No. 4. Sketches of the Orient: Scenes in Asia.

No. 5. O1d Ocean: Winds, Currents and Perils.

No. 6. Iife in the Sea: Fish and Fishing.

No. 7. Bits of Bird Life: Habits, Nests and Eggs.

No. 8. Our Little Neighbors: Insects, Small Animals.

No. 9. At.Home in the Forest: Wild Animals.

No. ro. In Alaska: Animals and Resources.

No. Ir. Among the Rockies: Scenery and Travel.

No. 12. In the Southwest: Semi-Tropical Regions.

No. r3. On the P1ains: Pioneers and Ranchmen.

No. I4. The Great Lake Country: A Land of Progress.

No. r5. On the Gulf: Attractive Regions of Contrasts.

No. r6. Along the Atlantic: New York to Georgia.

No. r7. In New England: The Home of the Puritans.

Price 10 Cents Each, Postpait.

PERRY MASON \& COMPANY, Publishers, 


\title{
BITS OF BIRD LIFE.
}

\author{
SELECTIONS \\ From The Youth's Companion.
}

Number Seven.

CONTENTS.

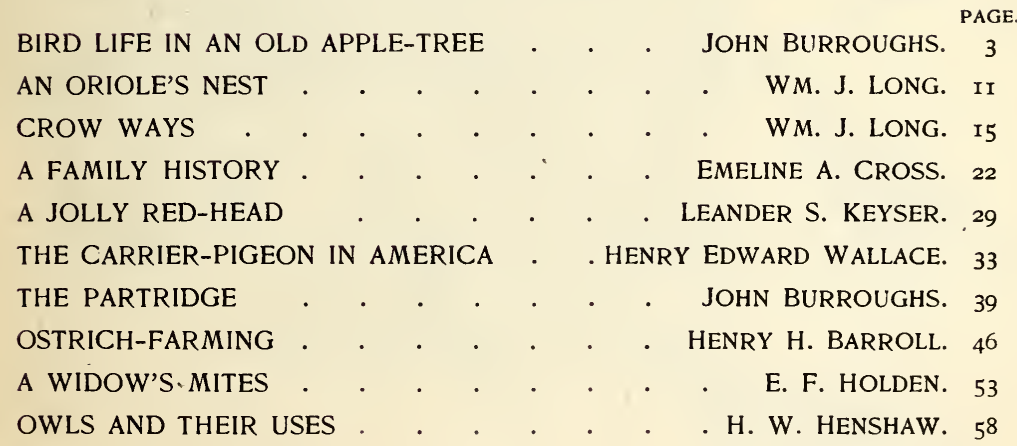




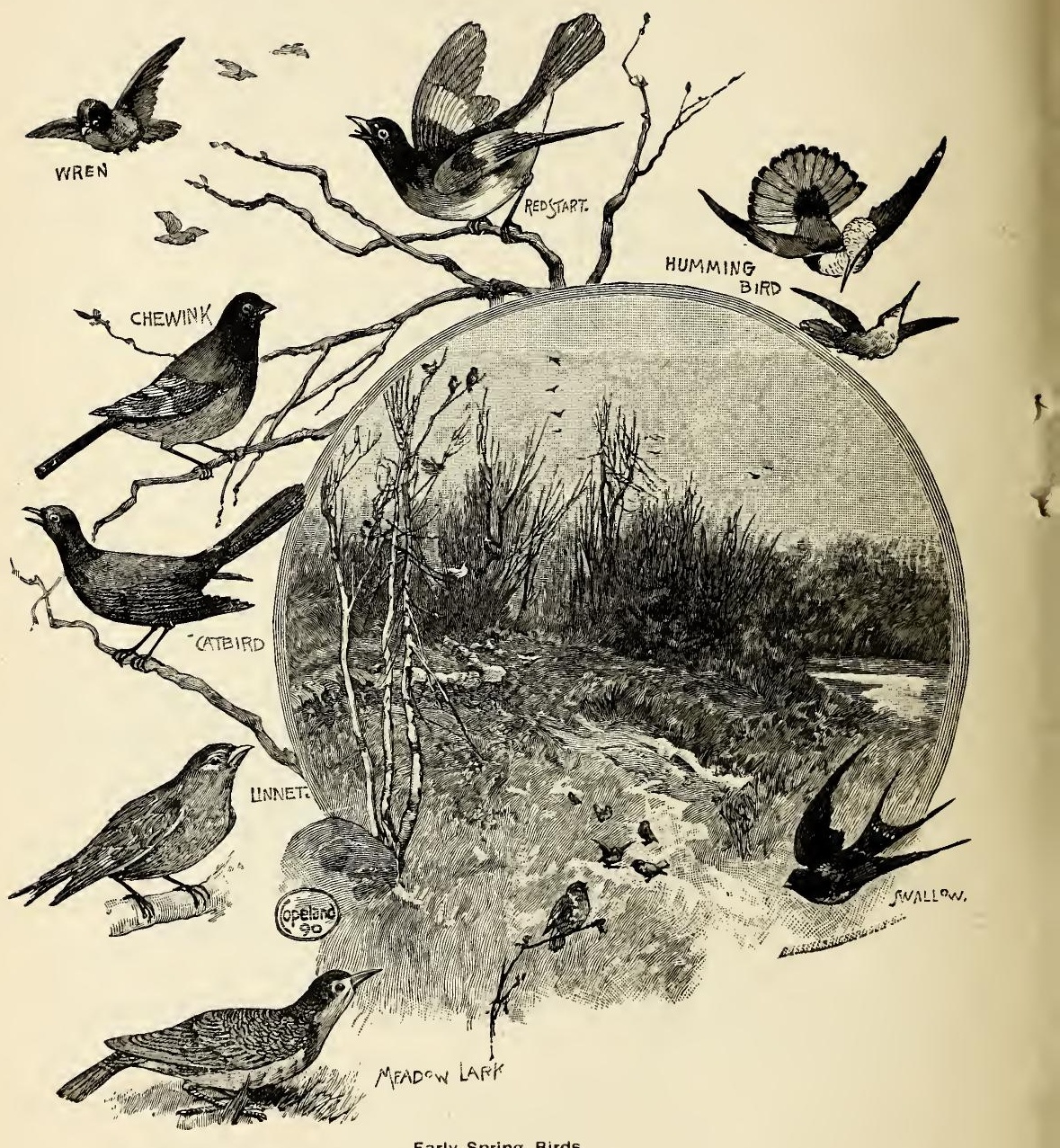

Early Spring Birds. 


\section{Bird Life in an Old Apple-Tree.}

Near my study there used to stand several old apple-trees that bore fair crops of apples, but better crops of birds. Every year these old trees were the scenes of bird incidents and bird histories that were a source of much interest and amusement.

Young trees may be the best for apples, but old trees are sure to bear the most birds. If they are very decrepit, and full of dead and hollow branches, they will bear birds in winter as well as summer. The downy woodpecker wants no better place than the brittle, dozy trunk of an apple-tree in which to excavate his winter home.

My old apple-trees are all down but one, and this one is probably an octogenarian, and I am afraid cannot stand it another winter. Its body is a mere shell not much over one inch thick, the heart and main interior structure having turned to black mold long ago.

An old tree, unlike an old person, as long as it lives at all, always has a young streak, or rather ring, in it. It wears a girdle of perpetual youth.

My old tree has never yet failed to yield me a bushel or more of gillyflowers, and it has turned out at least a dozen broods of the great crested flycatcher, and robins and bluebirds in proportion. It carries up one large decayed trunk which some one sawed off at the top before my time, and in this a downy woodpecker is now, January I2th, making a home.

Several years ago a downy woodpecker excavated a retreat in this branch, which the following season was appropriated by the bluebirds, and has been occupied by them nearly every season since.

When the bluebirds first examined the cavity in the 
spring, I suppose they did not find the woodpecker at home, as he is a pretty early riser.

I happened to be passing near the tree, when on again surveying the premises one afternoon, they found him in.

The male bluebird was very angry, and I suppose looked upon the innocent downy as an intruder. He seized on him, and the two fell to the ground, the speckled woodpecker quite covered by the blue coat of his antagonist. Downy screamed vigorously, and got away as soon as he could, but not till the bluebird had tweaked out a feather or two.

$\mathrm{He}$ is evidently no fighter, though one would think that a bird that had an instrument with which it could drill a hole into a tree could defend itself against the soft-billed bluebird.

Two seasons the English sparrows ejected the bluebirds and established themselves in it, but were in turn ejected by the undersigned, their furniture of hens' feathers and straws pitched out, and the bluebirds invited to return, which later in the season they did.

The new cavity which downy is now drilling is just above the old one and near the top of the stub. Their wells are usually sunk to a depth of six or eight inches, but in the present case it cannot be sunk more than four inches without breaking through into the old cavity.

Downy seems to have considered the situation, and is proceeding cautiously. As she passed last night in her new quarters I am inclined to think it is about finished, and there must be at least one inch of wood beneath her. She worked vigorously the greater part of the day, her yellow chips strewing the snow beneath.

I paused several times to observe her proceedings.

After her chips have accumulated she stops her drilling and throws them out. This she does with her beak, shaking them out very rapidly with a flirt of her head.

She did not disappear from sight each time to load her beak, but withdrew her head and appeared to seize the fragments as if from her feet. If she had had a companion 
I should have thought he was handing them up to her from the bottom of the cavity. Maybe she had them piled up near the doorway.

The woodpeckers, both the hairy and the downy, usually excavate these winter retreats in the fall. They pass the nights and the stormy days in them. So far as I have observed they do not use them as nesting-places the following season.

Last night when I rapped on the trunk of the old appletree near sundown, downy put out her head with a surprised and inquiring look, and then withdrew it again as I passed on.

I have spoken of the broods of the great crested flycatchers that have been reared in the old apple-tree. This is by no means a common bird, and as it destroys many noxious insects I look upon it with a friendly eye, though it is the most uncouth and unmusical of the flycatchers.

Indeed, among the other birds of the garden and orchard it seems quite like a barbarian.

It has a harsh, froglike scream, form and manners to suit, and is clad in a suit of butternut brown. It seeks a cast-off snakeskin to weave into its nest, and not finding one, will take an onion skin, a piece of oiled paper, or large fish scales.

It builds in a cavity in a tree, rears one brood, and is off early in the season. I never see or hear it after August ist.

A pair have built in a large, hollow limb in my old appletree for many years. Whether the same pair or not I do not know. Probably it is, or else some of their descendants.

I looked into the cavity one day while the mother bird was upon the nest, but before she had laid any eggs. A sudden explosive sound came up out of the dark depths of the limb, much like that made by an alarmed cat. It made me jerk my head back, when out came the bird and hurried off. For several days I saw no more of the pair, and feared they had deserted the spot. But they had not; they were 


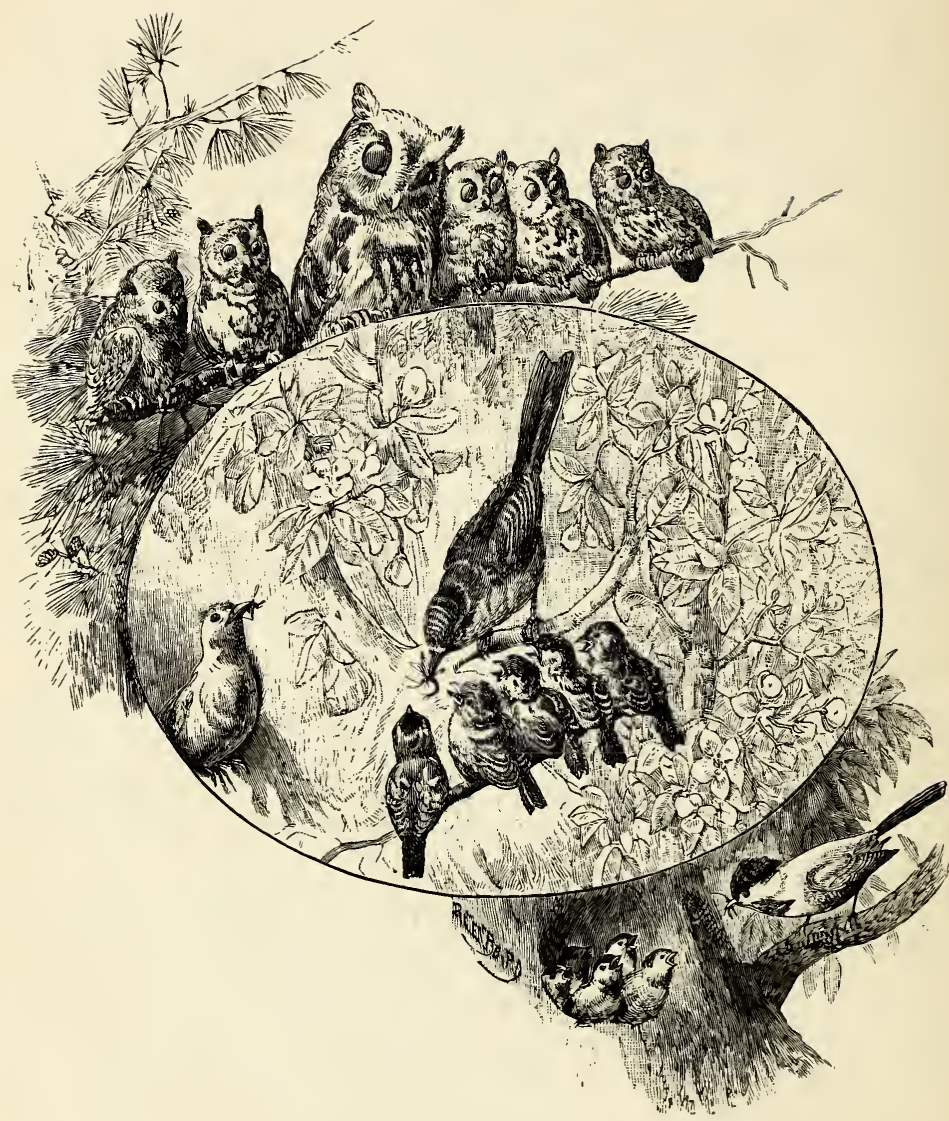

Three Happy Families. 
only more sly than usual. I soon discovered an egg in the nest, and then another and another.

One day as I stood near by, a male bluebird came along with his mate, prospecting for a spot for a second nest. $\mathrm{He}$ alighted at the entrance of this hole and peeped in.

Instantly the flycatcher was upon him. The blue was enveloped by the butternut brown. The two fell to the ground, where the bluebird got away, and in a moment more came back and looked in the hole again, as much as to say, "I will look into that hole now at all hazards."

The barbarian made a dash for him again, but he was now on his guard and avoided her.

Not long after, the bluebirds decided to occupy the old cavity of the downy woodpecker from which I had earlier in the season expelled the English sparrows. After they had established themselves here a kind of border war broke out between the male bluebird and the flycatchers, and was kept up for weeks.

The bluebird is very jealous and very bold. He will not even tolerate a house-wren in the vicinity of his nest. Every bird that builds in a cavity he looks upon as his natural rival and enemy. The flycatchers did not seek any quarrel with him as long as he kept to his own domicile, but he could not tolerate them in the same tree.

It was a pretty sight to see this little blue coat charging the butternut through the trees. The head of the latter would click like a gunlock, and its harsh, savage voice was full of anger, but the bluebird never flinched and was always ready to renew the fight.

The English sparrow will sometimes worst the bluebird by getting possession of the box or cavity ahead of him. Once inside the sparrow can hold the fort, and the bluebird will soon give up the siege; but in a fair field and no favors, the native bird will quickly rout the foreigner.

Speaking of birds that build in cavities reminds me of a curious trait the highhole has developed in my vicinity, one which I have never noticed or heard of elsewhere. 


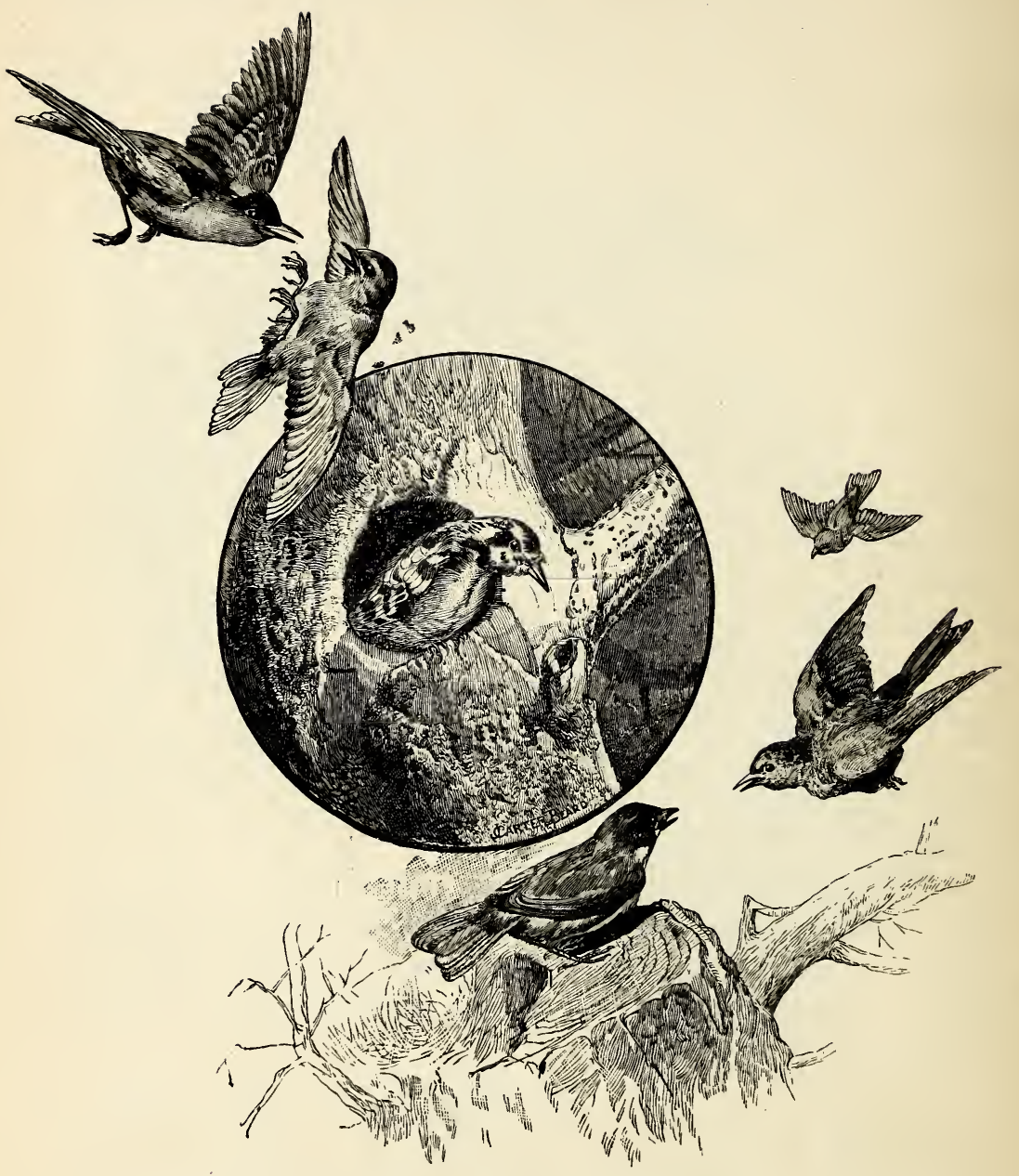

Bird Life in an Old Apple-Tree. 
It drills into buildings and steeples and telegraph poles, and in some instances makes itself a serious nuisance.

One season the large Grecian columns made of wood of an unoccupied old-fashioned summer residence near me were badly marred by them. The bird bored into one column, and finding the cavity - a foot or more across - not just what it was looking for, cut into another one, and still into another. Then he bored into the ice-house on the premises, and in the sawdust filling between the outer and inner sheathing found a place to his liking.

Every season of late years they bore into the large icehouse on the banks of the river, and cut so many holes and let out so much sawdust that the men employed about the place have had to shoot them.

One bird seemed like a monomaniac, and drilled holes up and down and right and left as if possessed of an evil spirit. It is quite probable that if a highhole or other woodpecker should go crazy, it would take to just this sort of thing, drilling into seasoned timber till it used its strength up. The one I refer to would cut through a dry hemlock board in a very short time, making the slivers fly. The sound was like that of a carpenter's hammer. It may have been that he was an unmated bird, a bachelor whose suit had not prospered that season, and was giving vent to his outraged instincts in drilling these mock nesting-places.

JOHN BURROUGHS.

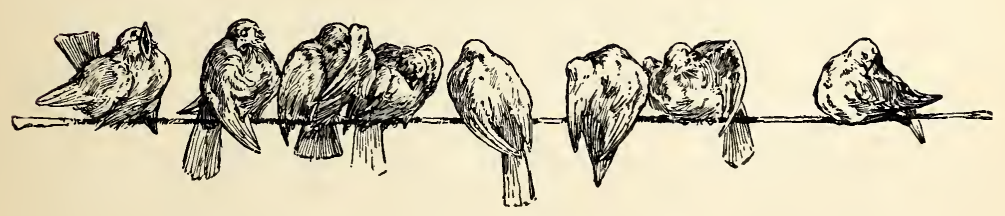




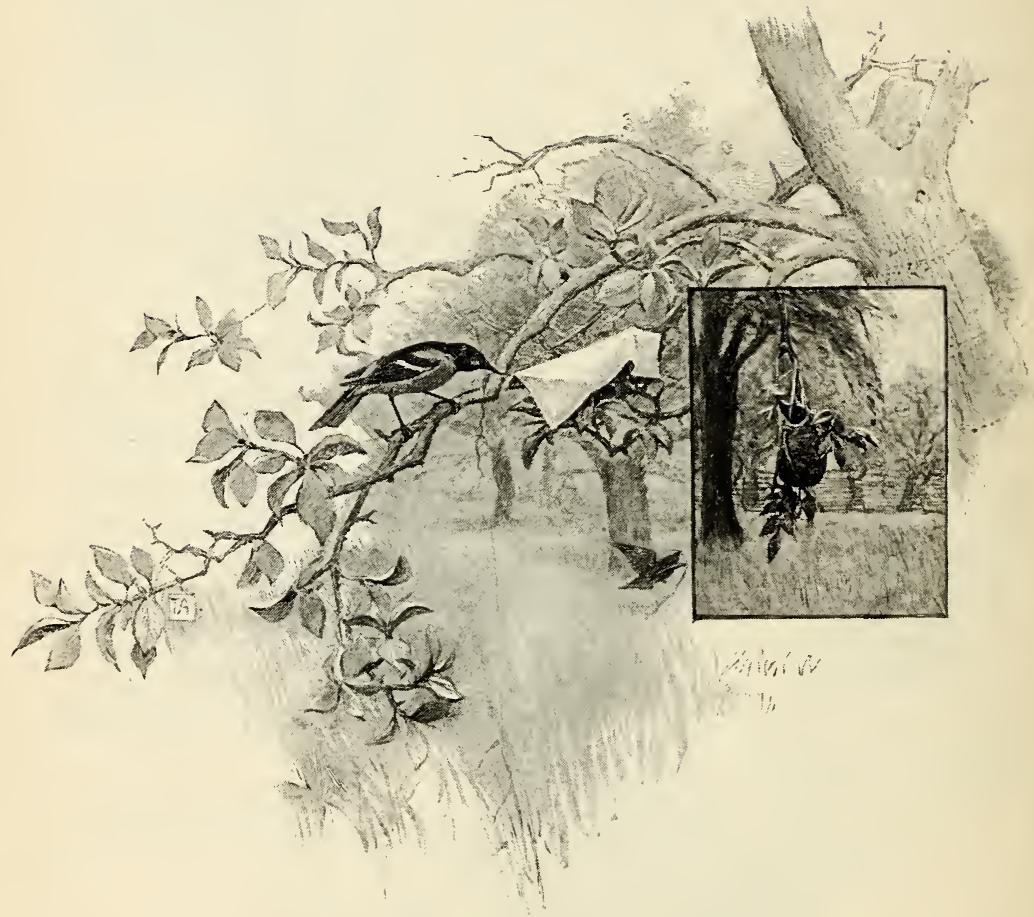

Oriole and its Nest. 


\section{An Oriole's Nest.}

How suggestive is the oriole's nest, swinging from the long, drooping tips of the old elm boughs! What a delightful cradle it must be for the young orioles, swayed all day long by every breath of the summer breeze, and with never a fear of falling! And the mother-bird must feel very comfortable about it as she leaves it to go in search of food, for no birdenemy will trouble it while she is gone.

The blacksnake - that horror of all low-nesting birds will never climb so high. 'The red squirrel - little cannibal that he is, eating flesh when he has still a bushel of nuts and acorns stowed away in his old wall - cannot find a footing on those delicate branches. The crow also can find no restingplace from which to steal the young, should he ever venture so near the house; and the hawk's legs are hardly long enough to reach down and grasp them, should he perchance hover over the nest.

Yet the oriole is a neighborly little body. Though her young are kept from harm by the cunning instinct that builds a hanging nest, she still prefers to build close by the house, where hawks and crows and owls rarely come. She knows her friends, and takes full advantage of their protection, returning year after year to the same old elm, and like a provident little housewife, carefully saving and sorting the good threads of her old house to be used in building the new.

Of late years, however, it has seemed to me that the beautiful nests along the elm-lined streets of New England towns are growing scarcer. The orioles are sunny, peace-loving birds, and dislike the society of those noisy, pugnacious little rascals, the English sparrows. Often I now find their nests along lonely old roads in places where a few years ago I never saw them; and often a solitary farmhouse, too far 
away from the town to be troubled by sparrows, has two or three orioles' nests in the boughs of its old elms.

I know of three old, lonely houses, deserted for years, and fast falling to piles of ruins, where every year the orioles return to build, untroubled by sparrows, and still protected by the old walls and chimneys from the presence of hawks and crows.

It is a curious evidence of the birds' keen instinct, that where the nests are built on lonely roads away from houses they are noticeably deeper, and so better protected from birdenemies. The same thing is noticed of the nests that are built in other than elm-trees, and so have not the protection of the elm's drooping branches.

In the choice of building material the birds are very careful. They know well that no branch supports the nest from beneath; that the safety of the young depends solely on good strong material well woven together. In some wise way they seem to know at a glance whether a thread is strong enough to be trusted; but sometimes, in selecting the first threads that are to bind the whole nest to the branches, they are unwilling to trust to appearances. Then a pair of birds may be seen holding a little tug-of-war with feet braced and heads twisted first on one side, then on the other, till the thread is well tested.

In gathering the material also the birds display no little ingenuity.

One warm spring day a few years ago I was lying under some shrubs watching a pair of orioles that were building close to the house. It was a typical nest-making day, the sun pouring his bright, warm rays through delicate green leaves and a glory of white apple blossoms, the air filled with warmth and fragrance, birds and bees busy everywhere. Orioles seem always happy, and to-day they quite overflowed in the midst of the brightness, though materials were rather scarce, and they had to be very busy.

The female was very industrious, never returning to the 
nest without some contribution, while the male frolicked ahout the trees in his brilliant orange and black, whistling his warm, rich notes, and seeming like a dash of southern sunshine amidst the blossoms.

Sometimes- he stopped in his frolic to find a bit of string, or to fly with the female to the nest, uttering that soft, rich twitter of his as if in congratulation, whenever she found some particularly choice material. But his chief part seemed to be to furnish the celebration, while she took care of the nest-making.

Out on the grass directly in front of me was a small fragment of white cloth. I was wondering why the birds did not utilize it when the male, in one of his lively flights, seemed to see it for the first time and flew down. First he hopped about it on all sides, then took hold of some threads at one corner and tried to pull them out. But the cloth was lying loose on the grass, and whenever he pulled, the whole piece came instead of the threads.

For a few moments he worked diligently, trying a pull on every side, once tumbling over with a comical scramble as the cloth, caught for a moment on a grass stub, gave way when he pulled hardest. Quite abruptly he flew away, and I thought he had given up the attempt.

But in a minute back he came with the female, thinking no doubt that, as a prudent little manager, she would know all about such things. If birds do not talk they have at least some very ingenious ways of letting one another know what they think - which amounts to much the same thing.

The two birds worked together for some minutes, getting an occasional short thread, but not enough to pay for the labor. The trouble was they both pulled together, and the cloth kept slipping. Once they unravelled a long thread by pulling at right angles, but the next moment they were on the same side again. Twice they left it and came back again.

I was wondering how long their patience would last when 
the female suddenly seized the cloth by the corner and flew with it along the ground, chirping loudly the while. She disappeared into a low crab-apple bush at the corner of the garden. The male followed a moment later.

Curious as to what they were doing, yet fearing to disturb them, I waited a few moments, and soon saw both birds fly to the nest, each with some long white threads. This was repeated; and while the orioles were busy at the nest I ran round the house and crept down behind an old wall where I could see the crab-apple.

They had solved their problem - the piece of cloth was fastened there among the thorns! Soon the birds came back, and seizing the ends of some threads, ravelled them out and flew away to their building.

For nearly an hour I watched them while they worked from that bit of cloth to the nest. Several times it slipped away from the thorns, but as often as it did so the birds carried it back and fastened it; till at last it grew so snarled and torn that they could get no more threads, and left it for good.

That same day I carried out some bright bits of worsted and narrow ribbons, and scattered them about on the grass. The birds soon found them and wove them into the nest. For a time a gayer little dwelling never was seen in a tree. The bright bits of color among the gray and white gave it always a holiday appearance, in good keeping with the high spirits of the two birds. But by the time the young had chipped the shell, and the joyousness of nest-building had given place to the sober duties of feeding hungry little mouths, the rains and the sun of summer had bleached the bright colors into a uniform, sober gray.

That was a happy family from beginning to end. No accident ever befell it; no enemy disturbed its peace. And when the young birds had flown away to the south, I took down the nest I had helped to build and hung it in my study as a souvenir of my bright little neighbors.

WM. J. LONG. 


\section{Crow Ways.}

With all his rascality, the crow has many curious and interesting ways. Indeed, I hardly know another bird that so well repays a season's study. Only one must be very patient and endure frequent disappointments if one would learn much of a crow's peculiarities by personal observation.

How shy he is-how cunning and quick to learn wisdom! Yet he is very easily fooled, and some experiences that ought to teach him wisdom he seems to forget within an hour. Almost every time I go shooting I get one or two crows from a flock that ranges over my hunting-ground by simply hiding among the pines and calling like a young crow. It is astonishing to hear the loud chorus of haw-haws, and see its members come rushing over the same grove where a week before they were fooled in the same way.

Sometimes, indeed, they seem to remember, and when the pretended young crow begins his complaint at the bottom of some thick grove, they collect on a distant pine-tree, and haw-haw in vigorous protest. But curiosity gets the better of them, and they generally compromise by sending over some swift, long-winged old flier.

Over he comes, fast as he can fly, and the crowd stop their clatter to watch results. Down he tumbles through the pine tops, at the report of a gun ; and away they go, screaming at the tops of their voices, and never stop till they are safe across the valley. Next week they will act in exactly the same way.

Crows, more than any other birds, are fond of excitement and great crowds. The slightest unusual object furnishes an occasion for an assembly to investigate.

A wounded bird will create as much excitement in a flock of crows as a railroad accident does in a village. All the 


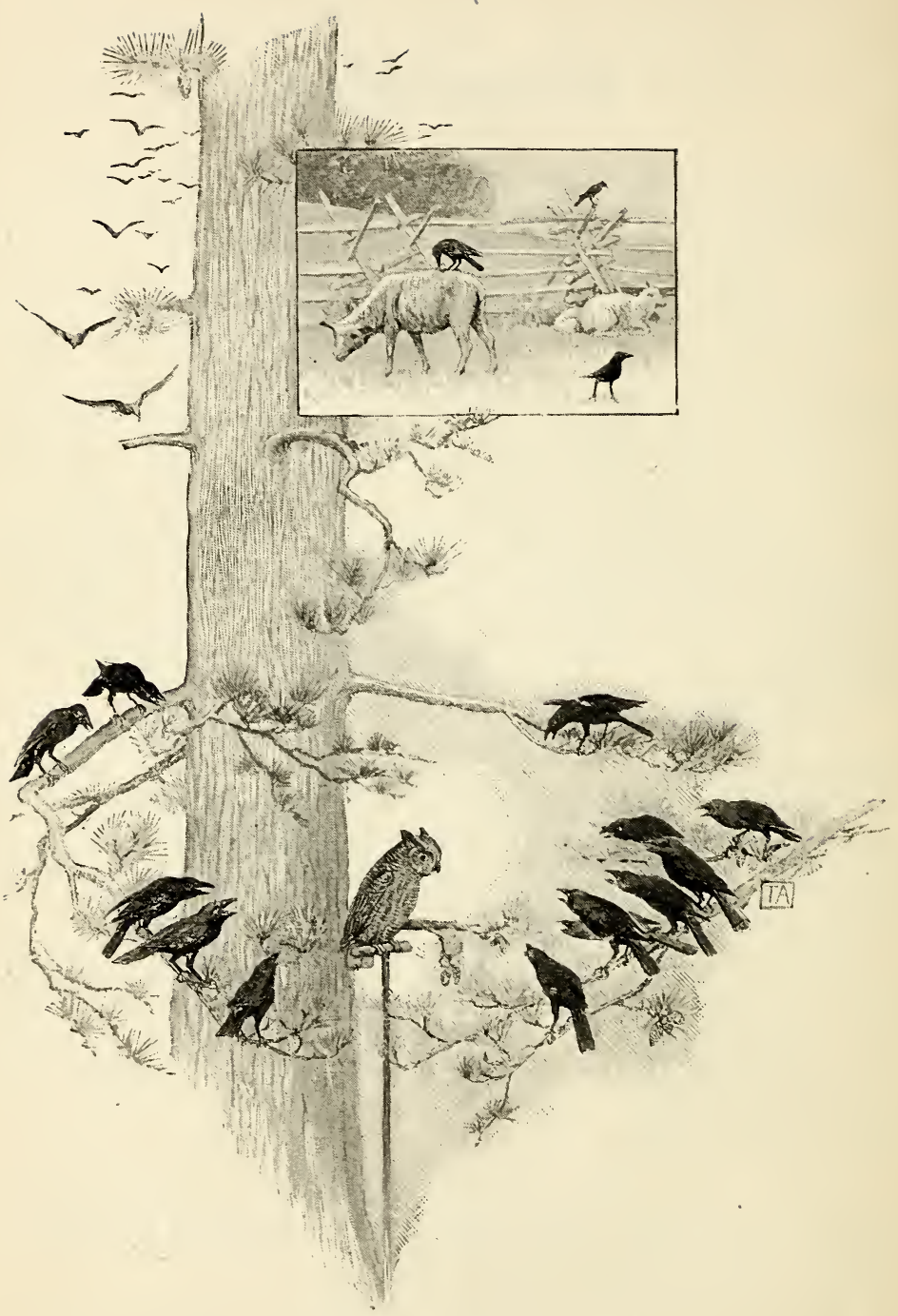

A Fuss over an Ow1. 
crows seem to be talking at once, and advising the poor fellow what to do.

When some prowling old crow discovers an owl sleeping away the sunlight in the top of a great hemlock, his delight and excitement know no bounds. There is a suppressed excitement in his very call that every crow in the neighborhood understands. "Come! come! everybody come!" he seems to be screaming, as he circles over the tree-top; and within two minutes there are more crows gathered about that hemlock than one would believe existed within miles of the place.

One day I counted over seventy immediately about a tree in which one of them had found an owl, and there must have been as many more flying about the outskirts that I could not count.

At such times one can approach very near with a little caution, and attend, as it were, a crow caucus. Though I have attended a great many, I have never been able to discover any real cause for the excitement.

Those nearest the owl sit about in the trees, cawing vociferously; not a voice is silent. Those on the outskirts are flying rapidly about, making if possible more noise than the inner ring, and apparently urging speedy and vigorous measures against the culprit they have discovered. The owl meanwhile sits hidden in the green top blinking and staring and puffing out his long feathers till he looks twice his usual size.

Every moment two or three crows leave the ring to fly up close and peek in ; then go screaming back again. Hopping about on their perches, cawing at every breath, nodding their heads and striking the branches, they seem for all the world like excited stump-speakers. The din grows louder and louder; fresh voices are coming in every minute; and the owl, wondering in some vague way if he is the cause of it all, flies off to some other tree where he can be quiet and go to sleep. Then with a great rush and clatter the crows 
follow, some swift old crow keeping close to the owl and cawing all the way to guide the whole noisy rabble.

When the owl stops they gather round again, and go through the same performance more excitedly than before. So it continues till the owl finds some hollow tree and goes in out of sight leaving them to caw themselves tired; or else finds some dense pine grove and doubles about here and there with that shadowy, noiseless flight of his till he has thrown them off the
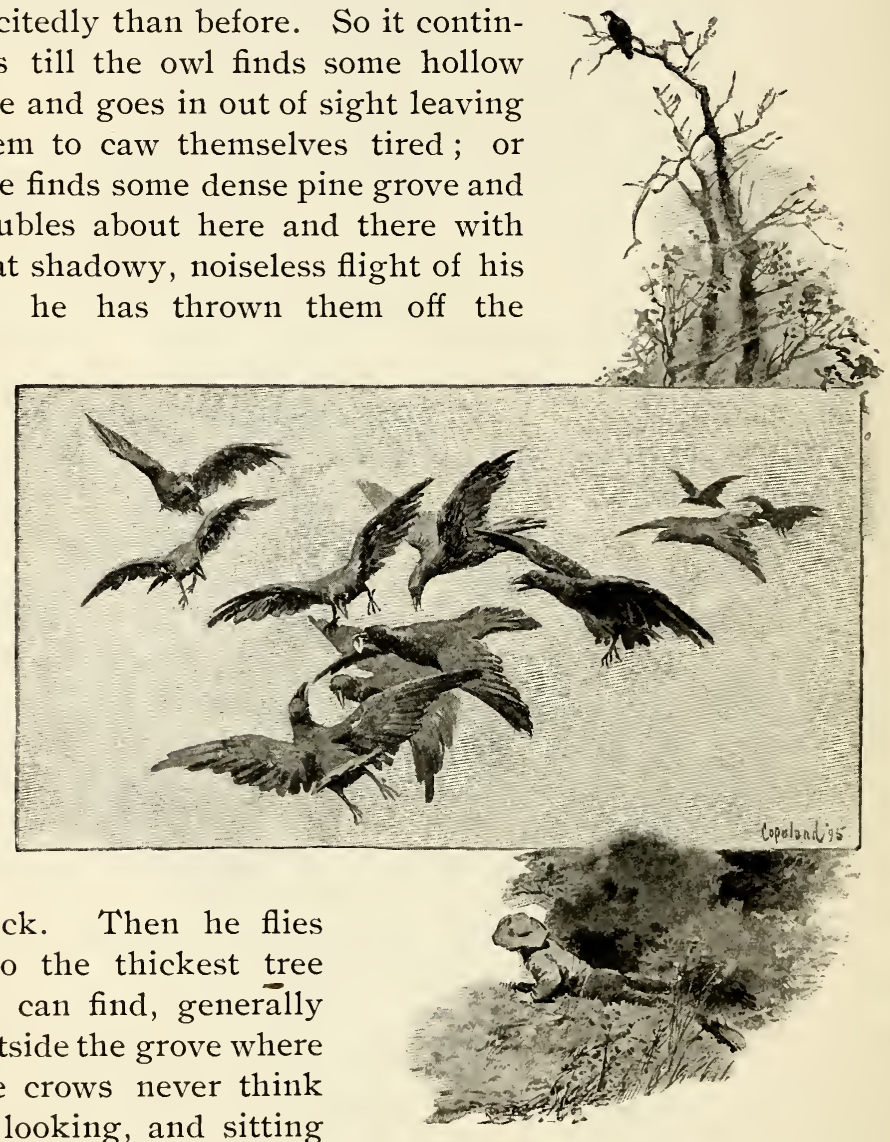

track. Then he flies into the thickest tree he can find, generally outside the grove where the crows never think of looking, and sitting close up against the trunk blinks his great yellow eyes, and listens to the mob that go sweeping through the grove, peering into every thick tree, and searching everywhere for their lost excitement. 
The crows give it up reluctantly. They circle for a few minutes over the grove, rising and falling and wheeling with that beautiful motion that seems like the practice drill of all gregarious birds; then end by collecting on some large tree at a distance and hawing about it till some new excitement calls them elsewhere.

Just why they grow so excited over an owl is uncertain. I have never seen them molest him. They only stare at him occasionally and make a great noise about it. That they recognize him as a thief and cannibal I have no doubt. But he thieves by night when other birds are abed, and as they practise their own thievery by open daylight it may be that they are denouncing him as an impostor.

Perhaps the owl in his nightly prowlings sometimes snatches a young crow off the roost - the great-horned owl would hardly hesitate to eat an old crow if he could catch him napping - and so the crows grow excited, as all birds do in the presence of their natural enemies. They make much the same kind of a fuss over a hawk, though he easily escapes the annoyance by flying swiftly away, or circling slowly upward till the crows grow dizzy and dare not follow.

Once I utilized this habit to get a near view of them. I carried out an old stuffed owl and set it up on a pole close against a great pine-tree on the edge of a grove where a flock of crows often congregated. Then I lay down in a thick clump of bushes near by and cawed excitedly.

The first messenger from the flock flew straight over without making any discoveries; the second one found the owl and I had no need of further calling. Haw-haw- he cried deep down in his throat - here he is! Here's the rascal! In a moment he had the whole flock there, and for ten minutes they kept coming in from every direction.

A more excited lot I never saw. The cawing was tremendous, and I hoped at last to settle the real cause of the excitement. But one crow flying close over my hiding-place discovered me peering out through the bushes. How he 
made himself heard or understood in the din is a mystery; but the crow is never too excited to heed a danger note. A moment later the whole flock was streaming away across the woods.

There is another but much more dignified way in which the crow's love of excitement is manifested. Occasionally a flock may be surprised sitting about in the trees deeply absorbed in watching a performance by one of themselves.

A crow's chief note is the hoarse haw-haw with which every boy is familiar. This, indeed, seems capable of expressing almost everything, from the soft, chattering gossip of going to bed in the pine tops to the loud derision with which he detects ordinary attempts to surprise him, but he is not always confined to it. Certain crows occasionally develop unusual vocal ability, and at times they seem to display it for the entertainment of the others. Yet I suspect that this vocal gift is seldom used or even discovered till lack of excitement throws them upon their own resources. Certain it is that whenever a crow exercises his voice there are always several more about, apparently listening attentively.

One September afternoon, while I was walking quietly through the woods, my attention was attracted by an unusual sound coming from an oak grove near by - a favorite haunt for gray squirrels. The crows were cawing in the same direction, but every few minutes would come a strange cracking sound-crrack-a-rack-rack, as if some one had a giant nut-cracker and was snapping it rapidly.

I stole forward till I could see perhaps fifty crows perched about in the oaks, all very attentive to something going on below them that I could not see. Not till I had crawled up to the brush fence on the edge of the grove and looked through did I discover the object of their interest. Out on the end of a long, delicate branch, a few feet above the ground, clung a small crow. He was swaying up and down like a bobolink on a cardinal-flower, balancing himself 
gracefully by spreading his wings, and every few minutes giving the strange cracking sound with a vigorous flirt of his wings and tail as the branch swayed upward. At every repetition the audience hawed. I watched the unusual performance for fully fifteen minutes before the crows saw me and flew away.

Several times since, when hunting, I have been attracted by unusual sounds mingled with the cawing of crows, and surprised the flock evidently watching a performance. Once in the Maine woods the call was so gruff and loud that I was completely deceived, and stole forward with heavy shells in my gun, expecting some strange animal. The only musical sound I ever heard from a crow was a whistling very much like the too-loo-loo of the blue jay, who belongs to the same family for all his bright colors, but deeper and louder, and without the middle roll or trill that always marks the blue jay's whistle.

The same love of excitement and variety leads the crows to investigate any unusual sight or sound in the woods. Sometimes they follow a fox which the hounds have started so that the hunter can trace his exact course, and reach the runaway in time for a shot. Often they go out of their way to warn other birds and animals of the approach of danger.

Once I saw a young crow - I knew he was young by his nasal voice - deliberately play a practical joke on the flock by hiding under a thick pine, and calling them over again and again till they discovered him and chased him away. In fact, whenever one hears a flock of crows cawing away in the pine woods, he may be assured that some excitement is afoot that will well repay his time and patience to investigate.

WM. J. LONG. 


\section{A Family History.}

Perhaps every reader of this knows a robin when he sees one, but it is one thing to know a bird by name and quite another to know the bird itself. I am sure that no boy or girl could watch a family of robins, as I did for nearly five weeks, and ever meet a robin afterward without greeting him as a friend.

It was early in May when my acquaintance began with the family whose history I am about to relate. Then I discovered that the pair had found a building-site to their liking in a fork of the apple-tree within ten feet of my window.

All that day and the next, in spite of the rain, Mr. and Mrs. Redbreast were busy plastering their adobe house. So steadily did they work, collecting sticks, grass and mud, and molding and shaping with breast and beak, that their home was all ready to move into by the second night.

When the nest contained four pretty blue eggs, the little wife began to set. The male would occasionally fly up to the nest and offer his spouse food, with many a tender caress. Then he would fly into a neighboring tree and call to her merrily, "Cheer up! cheer up!"

She had been setting twelve days when I thought, from Mr. Redbreast's frequent visits to the garden for worms, that his family had increased. Of this I was not sure until next day, when he came to the nest with a worm in his beak. His mate, instead of taking it from him, slowly rose and lowered her bill into the nest as if to whisper some secret to little ones there.

Then two tiny beaks rose to view, and opened to receive the morsel. Next instant Mr. Redbreast was off for another worm, and the little mother was lovingly covering her 
precious brood. They were three days old when I awoke one morning at four o'clock, and watched them as they ate their morning meal. During the next two hours food was brought to the nest fourteen times, and each time was eaten as greedily as if the little brood were on the verge of starvation.

So rapidly had the young birds grown by this time that four heads could be seen above the edge of the nest when the parents were away. They

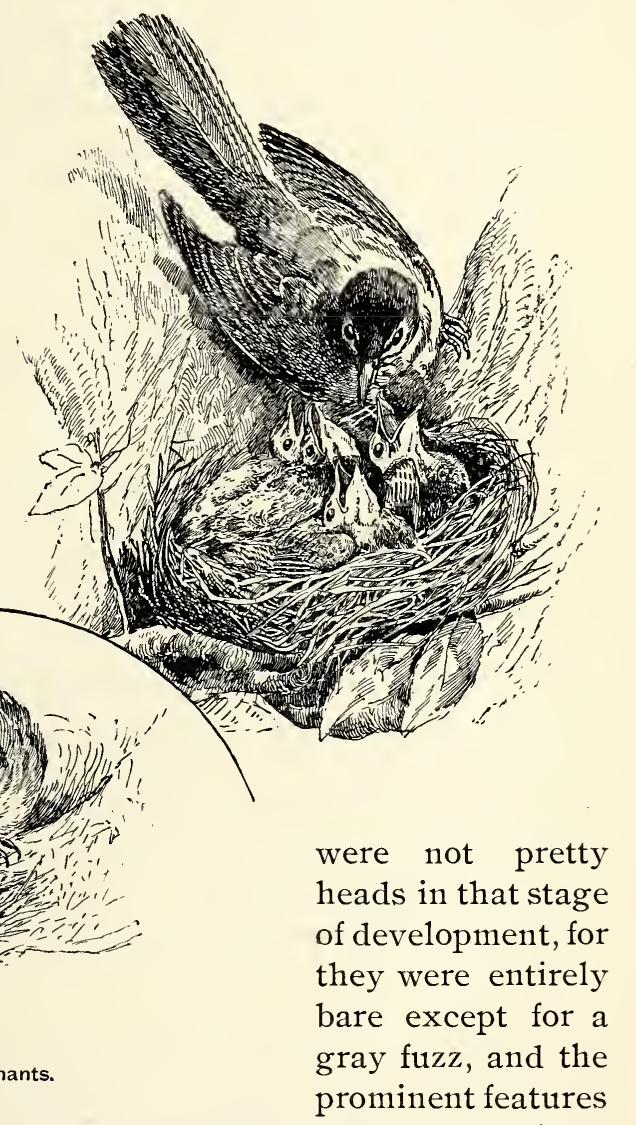

were an immense mouth and two bulging lumps on the sides. These lumps opened as eyes three days later.

The babies were now six days old and looked more like birds, though still far from being objects of beauty. They had grown so large as nearly to fill the nest, and at the 
slightest noise would lift up their heads high, and open their mouths wide. So long and slender were their necks, their heads so wide and flat, their beaks so long and opened to an almost incredible width, that there was something uncanny about them as they stretched up and uttered a queer little whine when either parent brought food.

I don't know where Mr. Redbreast spent his nights, but I do know that at half past three o'clock on the morning when the young birds were a week old, he flew up to his front door and fondly saluted his family. After a few moments, with a parting caress, to which the little mother responded in a contented twitter, he dropped from the twig by the nest. In a few minutes, with the air of one who was conscious of having done his duty, he returned with the first course of their morning meal.

The first faint streak of light was just showing in the east, but his day's work had begun. All day long, until after dusk, he and his mate were tireless in their search for food for the little ones.

The small folks in the nest grew more interesting every day. At ten days of age they were pretty well feathered and a very bright family. Two seemed brighter than the others, and were growing restless in their crowded nest. They would stand upon its edge, stretch their wings and necks, then stand on one foot, stretch out the other leg, and gape like a sleepy schoolboy. The home nest was getting too small for them, and the poor little mother was quite crowded out.

Two days later one of the young ones mysteriously disappeared, and I feared that he had fallen from the nest and become the prey of some prowling cat. But, probably, he had flown away, to begin life on his own account.

Now full fledged, they showed the robin markings distinctly - the black head, the light ring about the eye, the light throat and red breast prettily mottled above. The tail was the least developed, being not over three-fourths of an 
inch in length. As they sat in the nest it was elevated at such an angle that it pointed skyward, like the tail of a wren. It seemed incredible, that in less than two weeks from the time that they broke the shell of the egg, and in one week from the time they opened their eyes, they could have developed into such handsome creatures.

Beauties they were as they gazed at me so knowingly from above the edge of the nest. The three heads were close together, and each little face was full of expression, while they looked fearlessly into my eyes, as if trying to understand what sort of creature I was. Suddenly the mother flew into the tree with food for them. Instantly the heads lifted, the mouths opened wide, the wings fluttered, and every feather bristled with life and animation.

Their appetites being satisfied, they settled down for an after-dinner nap, with the three beaks pointing directly at me, and the eyes blinking drowsily.

And a nap they needed, for a tremendous quantity of food had gone into their stomachs since I sat down at the window an hour earlier. I wondered what a bird's digestive apparatus could be like, for worms, bugs, slugs and moths in great numbers all slipped down their gaping throats.

Once, a spear of grass, more than ten inches long, which hung from the father bird's beak, was eagerly seized by one of the youngsters. After a few convulsive gulps it disappeared down his throat.

But a robin's life is too short to be spent in providing food for hungry children, when they are old enough to begin to look for it themselves.

Several times during the day the mother came to the nest with food, held it tantalizingly in sight of the fledglings, allowed them to struggle for it, and then devoured it herself ! Was she urging them to seek their own food by tempting the appetite and then leaving it unsatisfied?

About five o'clock a faint chirp from the tree awoke me. 
One of the small birds stood on a limb, with his back turned to his old home and the wide world before him. Soon the mother came with food for the remaining ones, but no sign of recognition passed between her and the young adventurer. He flapped his wings two or three times, and with a hoarse croak flew clumsily into a neighboring tree. I did not see him again.

After the mother's next visit, the larger bird in the nest began to stretch. He stood on the edge of the nest, and looked curiously up and down among the branches for a few minutes. Then he spread his wings and flew a few feet, to a limb from which he looked around with wondering eyes.

The little bird left behind settled down contentedly for a while, turning around and pressing the nest, much as the mother did in shaping it, and all of the time making a soft, happy sound, as if pleased to have plenty of room. But his contentment did not last long.

Soon Mrs. Redbreast came with food, and with it, I fancy, she gave him some wholesome advice, for she had no sooner disappeared than he showed an inclination to follow his late companion who, when he saw the mother come to the nest, turned awkwardly around on his perch, and flew a little way toward her. She paid him no attention.

In less than five minutes the little fellow left behind mustered courage to try his wings. With a desperate spring from the side of the nest, he settled on a limb a few feet from the other bird. The parents for the next ten minutes called and coaxed and scolded from a neighboring tree, until the youngsters launched out and flew to them, one after the other. Soon all were out of sight, and my tree robbed of its treasures.

A few days after the nest was deserted I heard a queer, scratching noise in the tree, and saw a chipmunk peeping over the side of the nest, first at me, and then into the nest. Having satisfied himself that everything was all right, he briskly hopped into the nest, whirled around in it two or 
three times, and then cuddled down just as, in my childish fancy years ago, Goldilocks cuddled down when she "tried the little bear's bed." But Bunny didn't go to sleep. He filled the nest as completely as if it had been made for him, but it evidently did not suit him for a residence. After lying and blinking in it for a few minutes, he sprang out, scampered down the trunk of the tree, and was soon out of sight among the shrubbery.

Emeline A. Cross.

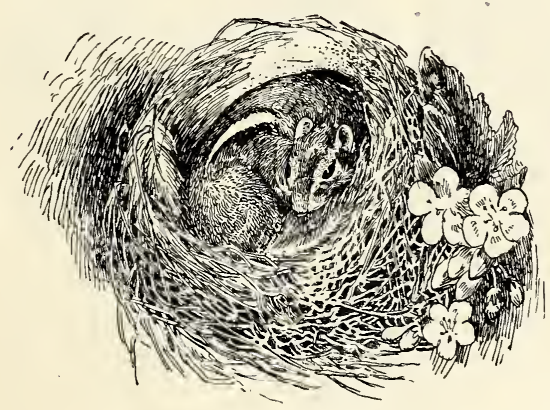




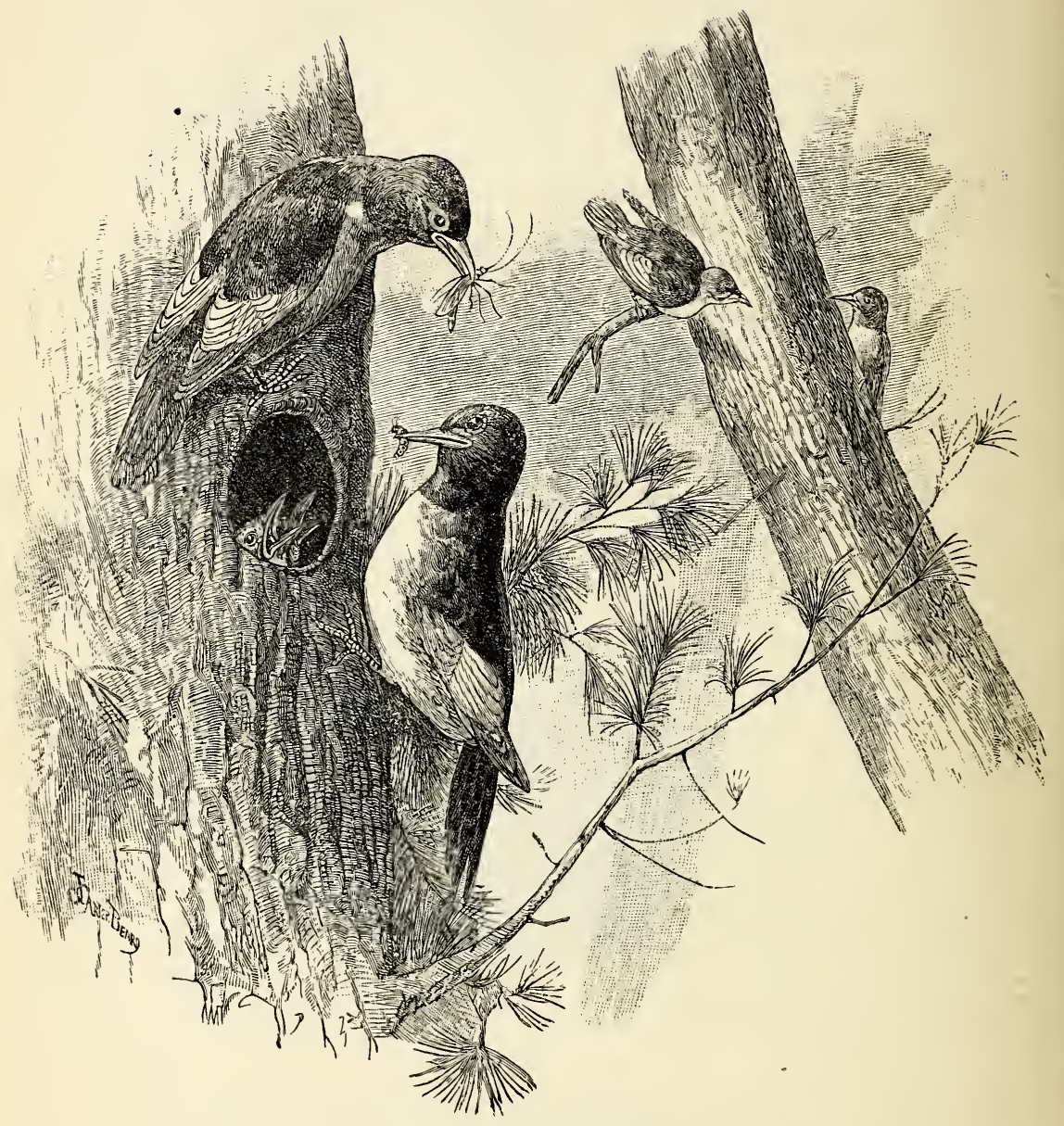

Red-Headed Woodpecker. 


\section{A Jolly Red-Head.}

One of the most interesting birds of my acquaintance is the red-headed woodpecker. In Ohio he is the most abundant species of the woodpecker family, the flicker coming next in point of numbers. You may see him almost everywhere; in the city as well as in the country; in the lowlands and meadows, if there are a few trees, as well as in the uplands; in the open spaces and in the dense woods, and wherever found, he is the same jolly, companionable fellow. I suppose every boy knows this bird, which, as Mr. Burroughs prettily says, "festoons the woods" with red, white and blue-black. He may be readily identified by his crimson head and neck, making him look as if he had plunged up to his shoulders into a keg of red paint.

Like all other woodpeckers, he is a hewer of timber, chiselling out a parlor-or rather, perhaps, a nursery-in a dead limb or tree-trunk, where he rears his young and trains them in the way they should go. I have known him to drill his nest in a fence-stake, while the telegraph poles along the railroad, although they must be hard and tough, often afford him a nesting place, and it is amusing to see him bolt from his cavity whenever a train dashes along.

It is regretted that our bird has not a more musical voice, and yet his well-known $g-r-r-u-k, g-r-r-u-k$ and $g-u-r-r-l$, $g-u-r-r-l$ and $k t-r-r, k t-r-r$ are by no means disagreeable, but are suggestive of the good nature and buoyancy of spirit that animate his bosom. If he is not much of a vocalist, he still seems to be a lover of music.

Listen to him as he plays a tune on that shellbark hickory-tree, or beats his tattoo on the slate roof. $\mathrm{He}$ evidently engages in this exercise, in part at least, for the sake of the musical effect, else why should he drum on the 
roof, where no insects are to be found, or upon an old tin pan that he has discovered out on the commons? There has been some dispute as to how he produces this quick succession of raps, several writers contending that he does it by rapidly striking together his mandibles. This cannot be the true explanation, for I have often watched him at his rehearsals, and have always noticed that the sound varies according to the object upon which he hammers.

For instance, if it is a large hollow tree, the sound is coarse and resonant, as one would expect. If he beats upon a piece of partly loosen bark, his tune is sharp and penetrating. On a tin or slate roof the sound is precisely what it would be if you or I should pound rapidly upon the same object with a similar instrument. But how can he beat so fast with his bill? Just as a drummer-boy deftly taps his snare-drum so rapidly that you cannot count the strokes, and almost think that his drumsticks must be small boards rounded at the end.

Of all the woodpeckers that I have studied, the redhead is the most expert on the wing. Of course he follows the fashion of the family when he flies, going in a kind of gallop from one perch to another. But other woodpeckers seem to regard flying as a serious business, and are therefore on the wing only as much as is necessary to secure food and escape from their foes.

Not so with our crimson-headed acrobat, who often performs the most amazing feats of scaling in the air out of pure exuberance of spirits. He must have some valve of escape for his rollicksome nature. And so he frequently hurls himself out into the air as if shot from a cannon, performs some exploit, such as poising, whirling, darting straight upward, and almost turning a somersault, and then circles gracefully back to his upright floor of bark, crying

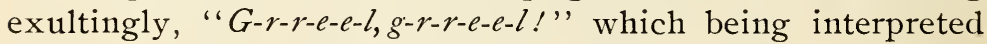
means, "Wasn't that a clever trick?"

Often, it is true, he makes a dash for an insect, just as 
the wood-pewee or the great crested flycatcher does; but I think that many of his feats are performed for pure love of frolic.

I have watched a dozen or more of these birds engaging in their wing-exercises in a favorite woodland, which might have been called their gymnasium. They had selected a certain tree for a point of departure, and with loud chattering would dash away after one another, describe a graceful circle, and then plunge back into the tree.

At times their cries seemed to be half-angry. Still, the whole performance seemed so jolly that it reminded me of a company of children playing "base" or "black-man."

These birds certainly have some sense of humor, and enjoy a romp as much as the most playful schoolboys.

One of their favorite pastimes is playing "hide-and-seek" about the trunks of trees. It is amusing to see two of them peep at each other a moment around the bole of a tree, and then jerk their heads back, precisely as you have seen children do. Besides, they often play "catch" or "tag," dashing pell-mell after each other among the trees, until you wonder they do not dash themselves to atoms.

A pair of bluebirds had a nest in a box near my house last spring. They seemed to be greatly vexed by the presence of a red-head which was in the habit of coasting on the maples along the street. They would make a quick dash at him, but the "artful dodger" would slip dexterously around to the other side of the tree out of harm's way.

Sometimes, however, he would stand his ground, and present his long spear of a bill to his enemies as they flung themselves at him, and thus keep them at a safe distance; for no bluebird would care to impale himself on the end of a lance like that.

Still the woodpecker would occasionally lose a feather by failing to be quick enough to evade the swift assaults of his enemies. I do not know whether he sometimes 
makes a raid on other birds' nests or not. I hope not; but I have noticed that robins and bluebirds have a mortal hatred of him, especially when he comes into the neighborhood of their nests.

Speaking of bluebirds in connection with the red-head, reminds me of a curious freak of bird-behavior that I observed one day in July. I was strolling along the banks of a small creek, when I saw a male bluebird sitting on a limb of an apple-tree, while only a few feet away, a redhead was busy at work in a cavity of the trunk (which he had evidently himself drilled), throwing out the chips at a lively rate, and at intervals peeping from the hole to see if the coast was clear.

I drove both birds away, and then watched them at some distance. In a few minutes the bluebird was again at his post, while his companion had gone back into the cavity to ply his trade of carpentry as before.

What did it mean? Was the bluebird playing the rôle of sentinel for the red-head? Or was the woodpecker hewing out a home for the bluebird by way of accommodation? Or was the bluebird only biding his time until the cavity should be done, when he intended to drive the busy toiler away, and occupy the nest himself? I have never been able to come to a decision in the matter.

From youth to old age our bird is a cunning, tricksy spirit. Ah! yes, there is the red-head, junior-but his head is black instead of crimson; so that we may say without contradicting ourselves that he is a black-headed red-head. $\mathrm{He}$ is a quaint lad. I have seen him clinging to the feathers of the parent bird, as a child to his mother's skirts, screaming for something to eat.

But when his stomach is full of titbits, he and his playmates have rare sport tobogganing (though they usually prefer to go uphill instead of down) on the trunks of trees, playing hide-and-seek, and flying race.

LEANDER S. KEYSER. 


\section{The Carrier-Pigeon in America.}

Amateur owners and breeders of carrier-pigeons are numbered by the thousands in this country. Nearly every city has a club or association devoted to the breeding and flying of these interesting birds. It is the opinion of good judges that, after a few generations, birds bred and flown in the United States become stronger and more sagacious than the European stock from which they are descended. Some of the best records, both for distance flown and for time, have been made by the pigeons of American fanciers.

The use of a carrier-pigeon post during the siege of Paris is a familiar fact. Newspapers, letters and despatches were reduced to diminutive size by photography, and entrusted to carrier birds, which had been brought out of Paris in balloons, and were thus carried back into the beleaguered city over the heads of the German army. During several months the pigeon-post was the only means by which the besieged city received news from the outside world.

But in spite of the telegraph, the telephone and the regular post, the services of pigeons are still often put to practical use in Europe. This is particularly the case in Belgium and the north of France, where they are most extensively bred. They are often employed successfully in carrying reports of speeches and other news from distant points to the Paris and Brussels newspapers.

American pigeon-fanciers have not devoted much attention to the practical side of their favorite diversion. Pigeon-flying here is regarded merely as a sport, and its principal object is the making of "records." There exists, however, near New York City a flock of these birds which demonstrates how easily they can be employed for a useful purpose. 
About forty miles from New York, amid the hills of Somerset County, New Jersey, a New York banker has a country estate, to which he has given the name of Chetola.

It is several miles distant from the nearest railroad and telegraph station. The proprietor has found a prompt means

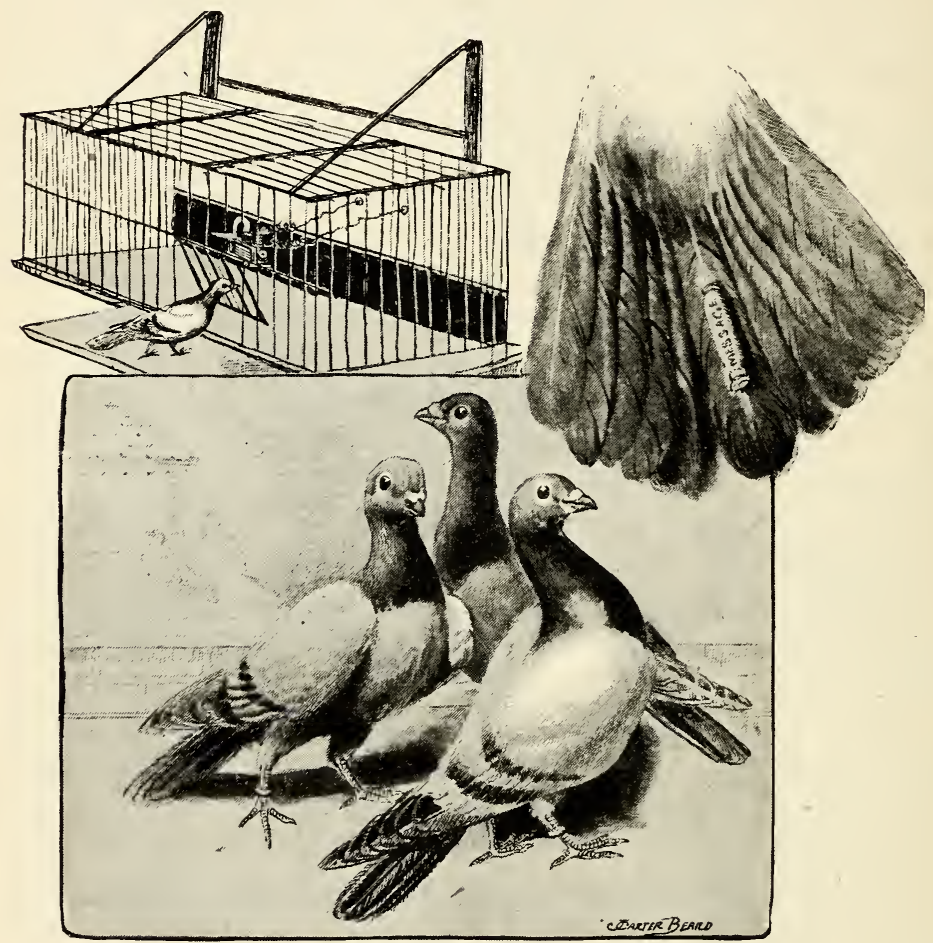

The Carrier-Pigeon.

of communicating with his place of business in the employment of trained pigeons; and the "Aërial Messenger Company, Limited," as the Chetola flock is called by its owner, has attained a high state of efficiency in its work.

About twenty-five birds are engaged in the service. 'They 
are the descendants of several pairs of Antwerp carriers imported by the owner. In appearance they are quite handsome, being longer in the body than the ordinary pigeon, with slim necks, bright, intelligent eyes, and large wings supplied with the abundance of muscular power necessary to sustain them in long and rapid journeys.

The general color of the birds is a slate-gray, with markings on the wings and body of a darker hue, melting on the neck and back into rainbow shades - the poetical, lively iris of the "burnish'd dove."

Their residence is a roomy loft over one of the farm buildings. Here they are provided with all the luxuries a pigeon can desire, including feeding-places constantly supplied with provender, and a continuous flow of water for drinking and bathing. Exceedingly fastidious birds, scrupulously neat as to their plumage, their dwelling-place must be kept in a condition of order and cleanliness.

The practical working of this Aërial Messenger service is simple. The birds are accustomed to being handled, and are not dismayed when some of their number are taken from the loft, placed in a wicker hamper, and carried by the railroad to New York.

Indeed, as some of them are always kept on hand at their owner's city office, they are habituated to this experience, and remain with apparent contentment in temporary seclusion.

While thus waiting for duty, their food and water are restricted to a minimum. When a message is to be entrusted to them, it is written out on a piece of very thin paper about three inches square. This is folded lengthwise into narrow compass, and one of the birds being taken from the hamper, the strip of paper is firmly attached to one of its tail feathers by means of a piece of fine wire.

A vigorous pull is always given to the feather to make sure that it is not loose. Then a window is opened, and the bird let loose. 


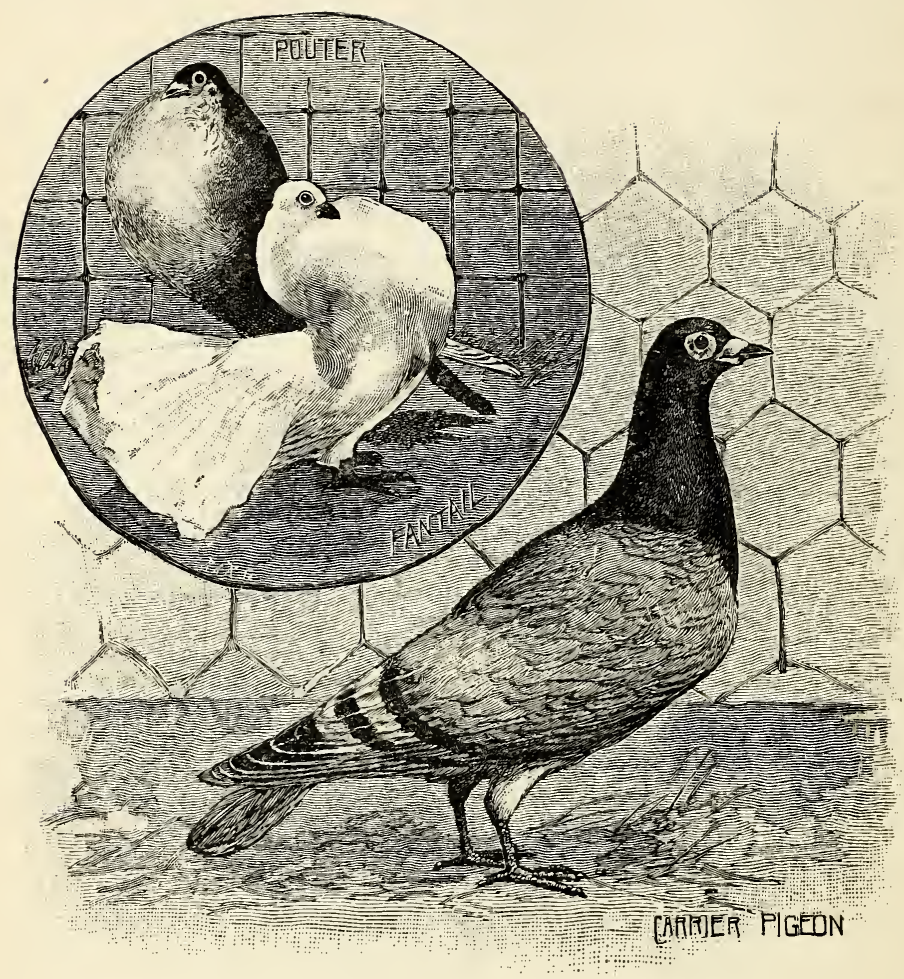


Instantly gaining its wings, it rises above the lofty buildings of the city, and without hesitation, strikes out in the direction of its home in New Jersey.

In from forty minutes to an hour the little messenger from Wall Street alights at its cote in the country. The entrance has a light swinging-door, which the bird easily pushes aside. In its desire for food and a bath after its long flight, it usually wastes no time in entering.

The door has an electrical attachment which signals the appearance of a bird by ringing a bell in the mansion. Some one at once goes to the pigeon loft, captures the newly arrived messenger, and relieves it of the note it carried.

In this way the master of the establishment can be kept by his partners and clerks fully informed of what is going on in the city.

Each bird in the service bears on its leg a light brass ring, upon which its number is inscribed. A careful record is kept of each trip a bird makes, and of the time it requires. Most of the flock have made the journey many times.

This precision was not attained without care and attention. Some birds, especially young and untried ones, never reappeared at their home after being despatched. They may fall victims to hawks or to undiscriminating gunners. Sometimes they are enticed from their duty by the prospect of food on the way, or join flocks of ordinary pigeons which they encounter.

Carrier-doves, like men, include some stupid and lazy individuals. Those who succumb to danger or temptation are caught or shot. The lazy birds, when freed, prefer to sun themselves on a roof rather than proceed with their message. Or on arriving at their home they roost for a time on a tree before entering their hospitable loft.

But by weeding out the weak or incompetent, by training the young birds to duty by flying them on gradually increasing distances, and above all by making their home attractive to them, this corps of feathered messengers has been brought 
to a state of assured efficiency. The "old stagers" have learned to avoid peril, to disdain allurements, and to attend strictly to business.

On one occasion a pair from this Chetola flock combined an important business service with a long distance flight.

Their master left New York in summer to spend some days at a fishing station on the New England coast, three hundred miles away from New York. He took with him a hamper containing a few birds, intending to test them on a long distance journey. The place at which he was staying was an isolated spot, far from a telegraph office, and was reached only by a steamboat on alternate days. One morning, after the steamboat had come and gone, he found that it had brought him a message from New York in regard to an important matter of business. An immediate answer was required, as the subject involved a considerable amount of money.

There was no way of sending a message for several days. He resolved to make use of his birds. He wrote the necessary instructions to his representatives in duplicate. The messages were attached to two of the birds, which were liberated at about two o'clock in the afternoon.

The next morning at seven o'clock the gallant carriers, having flown three hundred miles over an unfamiliar country, rang the bell that communicated with their loft in New Jersey. The messages were secured, and sent to New York at once; and the next mail brought the owner of the birds the information that his orders had been successfully carried out.

On this occasion alone, he says, the performance of the two birds repaid him a hundredfold for all the trouble or expense his faithful little feathered employés had ever cost him.

HenRY EDWARd WALLACE. 


\section{The Partridge.}

An interesting incident to me the past season was seeing, on two occasions, a partridge sitting upon her nest in the woods. It was an incident which one does not witness every season.

One of the partridges had come up out of the dense woods and nested near a path on the edge of a large cemetery. A bevy of schoolgirls, after wild flowers in May, first discovered her. Their skirts almost brushed her before she stirred. Her nest was at the foot of an oak a few yards from the open ground. She could command the approaches in all directions, and fly whichever way she chose.

My friend and I approached to within a few yards of her, and stood and regarded her to our hearts' content. Her color so blended her with surrounding objects that she was practically invisible. On such occasions the bird is as motionless as a stone, till she springs from her nest and is off on booming wing.

We did not disturb her this time, but withdrew as gently as we had approached. The brood was soon out and off, and I hope prosperous.

The other partridge was sitting upon her nest in the woods near an old road but little used. As it was late June, it was probably her second attempt at rearing a family. This is the more probable as she was sitting upon only five eggs, when from twelve to fifteen are the usual complement. Indeed, it may have been her third attempt.

Under the guidance of Martin, who lived near by, we approached and observed her from the road a few paces away. Martin had a task to pilot our eyes to the exact spot. One had to pass his eyes over the ground as he passes his hand over a table in the dark to find a pin. 

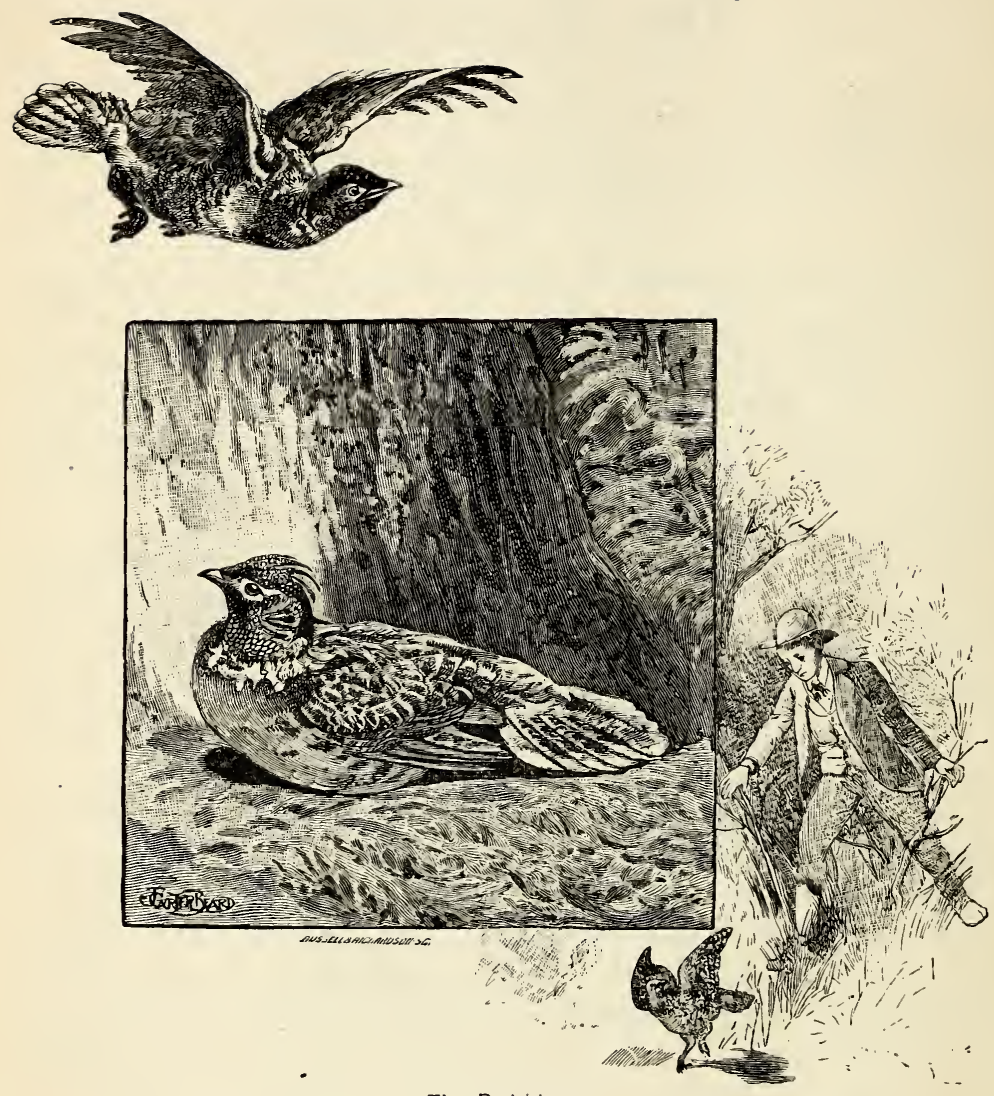

The Partridge. 
She, too, was at the foot of a tree, but the red leaves and the gray bark and the brown fragments of wood were all copied in her plumage.

Presently we made her out, and then we wondered we had not seen her before. After some moments we took a few steps toward her, when she went humming away. As she left the nest, she fanned the dry leaves so with her wings that several of them sprang up and settled upon the eggs, quite covering them.

I have observed this before. It is probably the result of design on the part of the bird. The nest is usually little more than a depression in the dry leaves, but its simplicity may be the result of a shrewd wisdom. If the bird ran from her nest before taking flight, she would seem to run less risk of breaking her eggs by the sudden withdrawal of her feet from among them; but in that case they would not be covered up by the leaves, as they usually are when she takes flight directly from the nest.

Martin kept his eye on the nest for me, and noted what time elapsed after the young were out of the shell before they were led away by the parent bird. One morning he visited them at nine o'clock, and the young were just out, as they were still moist. Apparently they had all hatched at the same time.

At noon he visited the place again, and found the nest empty; the brood was a few yards away. So brief is the period of helplessness of these creatures! After they can run they have little need of wings. The tactics of the mother and their own wit and protective coloring shield them most effectively.

As you come suddenly upon them, does the mother bird flee and tell her young to follow? Not a bit of it. She springs up with spread wings and tail, and would fain fill the space all about you with her presence and the sound of her wings and voice. She makes herself just as conspicuous and noisy as possible, and sets every dry leaf in commotion all 


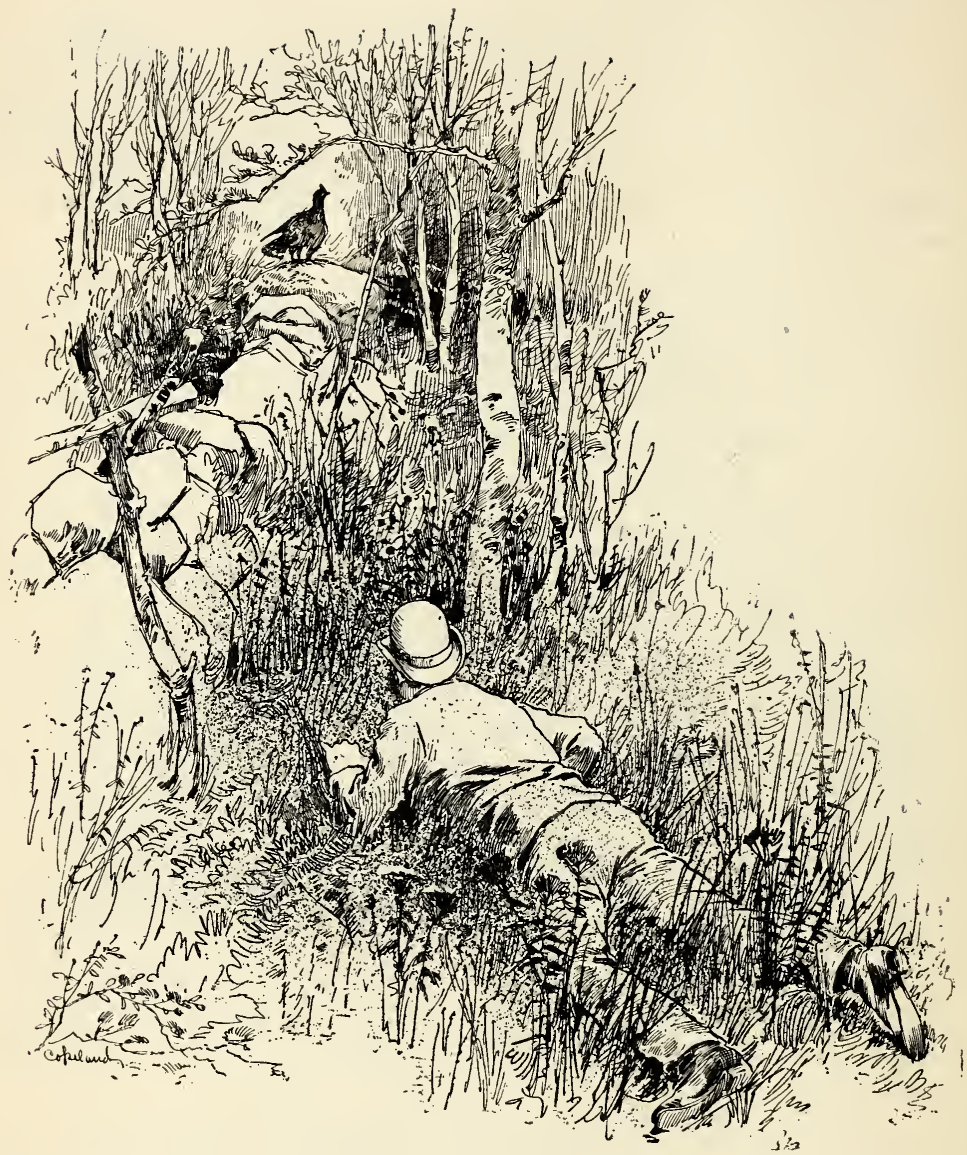

Waiting to hear him drum. 
about her. Under cover of this bluster the young scatter and hide in a twinkling. Before you have got over your surprise they have vanished like spirits, and the parent bird, lame and halt and apparently blind, flutters along before you, tempting you to stoop and pick her up, till she has lured you a few yards away, when she suddenly recovers herself and is gone.

Seeing how you have been fooled, you return to the spot and search for the young; but I have never known a person to find one under such circumstances.

I once caught one by refusing to have my attention diverted by the mother, and concentrating it on the young. One of them squatted amid the leaves which its parent's wings had set in motion, and I picked it up, when it squatted in the palm of my open hand.

After they can fly, the brood when disturbed scatter in all directions. The mother gives the signal, when up they all spring like an explosion. Union may be strength, but the young partridges know it is not safety for them. Later in the fall, when full grown, they will, on being flushed, usually all take the same general direction.

The hardiness and the cunning of the partridge will probably ensure its continuance in our woods in the face of all the guns and traps that are brought against it. It takes advantage of every circumstance. Think of it plunging beneath the snow and passing the night there, snug and warm; or of sitting down and letting the falling snow bury it.

When the hunter or walker comes upon it at such times, there is a sudden explosion in the snow at his feet as if some kind of frost cannon or mortar had been discharged, and he sees the brown missile go humming through the woods before him.

When the partridge cannot get food upon the ground, it can get buds upon the trees. Birch buds are its favorite, and when it wants a change it visits in the early morning the apple-trees in the orchard, or the wild apple-trees in the 
remote pasture. It is said that the complacent way in which the partridge allows itself to be snowed under sometimes brings it to grief. The storm changes to rain before morning, and then as suddenly it becomes cold and freezes, thus forming a crust beneath which the luckless bird is imprisoned. I have never seen anything of this kind, and cannot believe that this shrewd bird is often caught napping in this way.

The partridge has a cunning enemy in the fox, but I am convinced that Renard does not often have this choice morsel for his dinner. The oldest hunters report having seen but little evidence of this fact.

The hawk, too, rarely surprises it. I remember that once when I was a boy, on returning from the hay-field at noon, we found a partridge, nearly grown, at the edge of the woods with its head partly torn off, evidently by the stroke of a hawk. Nests are probably more

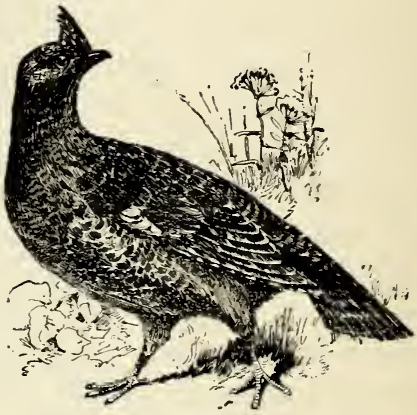
often broken up by crows and skunks. The partridge is preeminently the game bird of this country. It abounds almost everywhere, and it is always a challenge to the best skill of the sportsman. The hunting of it is full of surprises and disappointments. It is a kind of bitter-sweet pleasure, and hence about the most tonic pastime the country affords.

The country boy does not hope to shoot it on the wing in true sportsman fashion; this is a feat almost beyond his belief. He hopes to see it on the ground or in a tree, and kill it before it takes flight; and once in five or six years, if he is diligent, he will do so.

The first time I ever carried a gun alone into the woods I killed my first partridge. The gun was an old flint-lock musket, which my father had loaded for me. The partridge was upon the ground beside a small fallen tree; and she was 
evidently a kind-hearted bird, and wanted to give the boy a chance. She jumped upon the trunk of this little tree three or four rods from me and began to walk back and forth upon it with spread tail and elevated ruff, and uttering some chiding note, as if to say, " Now, little boy, now fire away."

I could not hold the old musket out at arm's length, so I sat down by a small bush, rested the gun upon a twig, took aim and began to pull the trigger.

I felt it begin to yield, and in half a breath expected the crash to come, when the twig broke and let my gun down upon the ground.

Still the game came promenading up and down the prostrate tree, jerking her tail and threatening to be off if I fooled much longer. I lifted the gun to another branch, took aim again, and pulled desperately.

The gun was discharged, and the grouse lay fluttering upon the leaves. I carried it home in great pride. Mother cooked it for me, and it was a part of my fare on the first journey I ever made out of my native county. This experience convinced me that the partridge was a very easy bird to kill; but it was years before I killed another one, and it was not because I did not make the effort to do so.

I did not find another bird so skeptical of my ability to injure it.

John Burroughs.

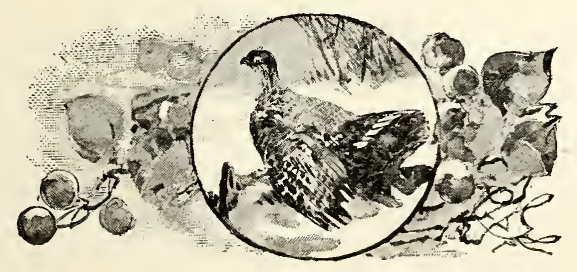




\section{Ostrich-Farming.}

Ostrich-farming was introduced into South America, whose pampas or great plains are peculiarly suited to this bird, in 1878 , by direct importation from South Africa. There is a species of the ostrich native to South America, but it is only half as large as the South African species, and its plumes are not so valuable.

The South African ostrich stands seven or eight feet in height, and weighs, when full grown, about one hundred pounds. The color of the plumage of the male is black and white, and of that of the female either dark gray or light brown. The female is quite as large as the male.

The ostrich's small head, which is not much larger than that of a goose, indicates a small brain and little intelligence. The long neck and legs, contrasting with the small head and body, give the bird an ungainly appearance.

Ostriches eat almost anything vegetable - grain, fruits of all kinds, potatoes, carrots, beets, and so on, besides grass, clover, and various weeds. Their digestion is powerful, and, to aid it, they continually accumulate in the gizzard small pebbles and sand.

The female is exceedingly careless about her eggs, laying them in any slight hollow, and often deserting her nest. The rearing of the birds, therefore, would hardly be profitable, if the hatching were not done by artificial heat. In some cases the females lay as many as fifty eggs in a season, but oftener not more than twenty-five or thirty.

The illustration represents the ostrich farm of Mr. Ambrose Sapello, at Las Piedras, near Montevideo, Uruguay. Mr. Sapello was the first to introduce ostriches into South America from the Cape of Good Hope, where, for twenty years, the profitableness of raising ostriches had been dem- 
onstrated. This farm now supports one hundred and ten ostriches. They are kept in pairs, and each pair is allotted a space of about two acres, which is sown to grass, and has in one corner a small hut in which the birds find shelter in wet weather.

These small lots are surrounded by a common wire or picket fence, about six feet high. The birds, kept in

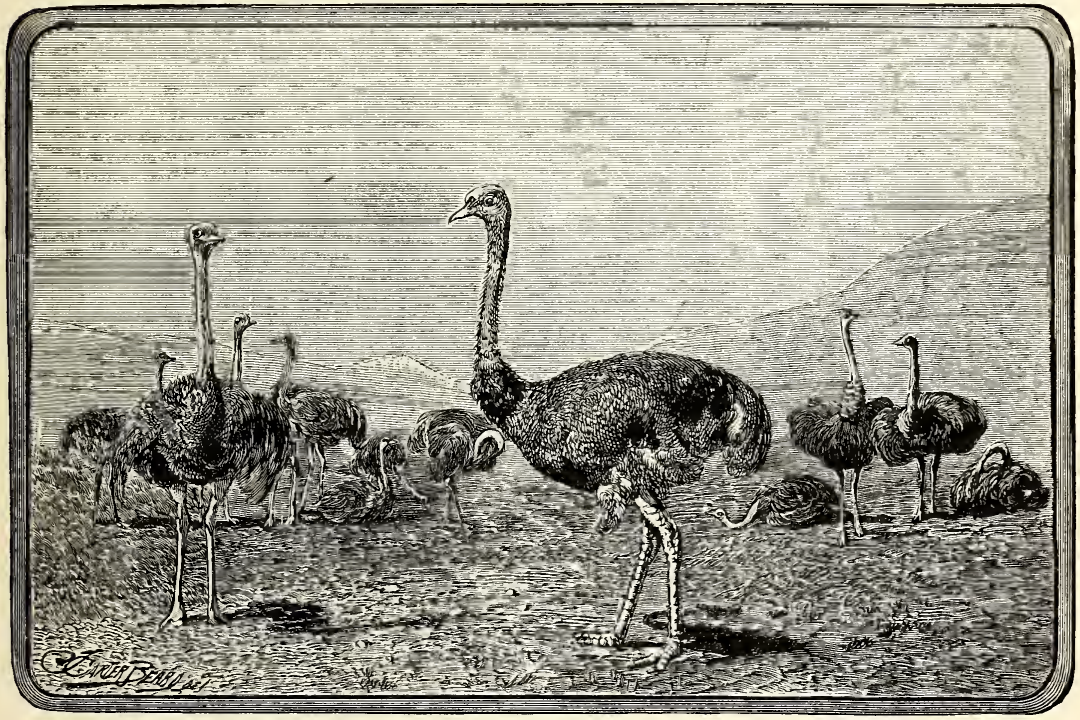

An Ostrich Farm.

constant sight of human beings, are not easily frightened. They have a great deal of curiosity; they approach to within a few feet of a person, and, if not interfered with, investigate with their great bills any bright object, such as a watchchain, locket, or breast-pin; but a sudden movement with the hand causes them to run clumsily but rapidly to what they consider a safe distance. 
The thick-shelled egg of the ostrich is twenty times as large as an ordinary hen's egg, and its weight is about two pounds. Before the eggs are placed in the incubator, or hatching-box, each one is placed in a long box which has at one end a lamp and at the other end a small opening for observation. If the egg is fruitful, an opaque spot will be observed in the yolk. If the yolk has a uniform density it is worthless.

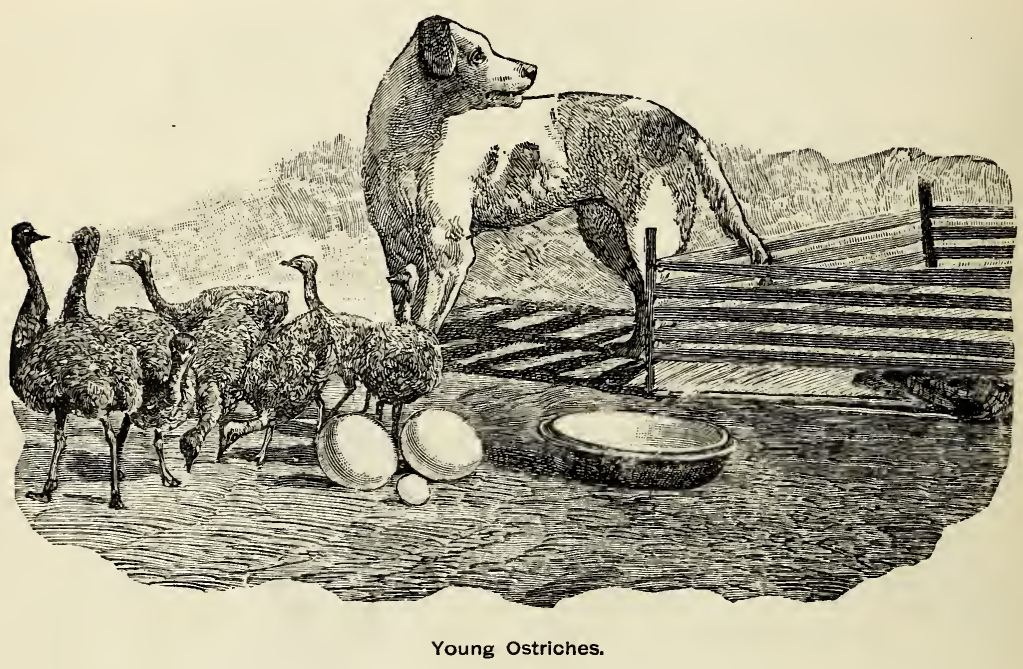

The eggs which pass this test are carefully placed in a cabinet consisting of a series of drawers, in which they rest upon soft felt. The temperature is raised to the required height by means of hot water from a large boiler near by. A thermometer attached to each drawer shows the exact heat. The temperature is kept between ninety-nine and one hundred and two degrees Fahrenheit.

At intervals of seven or eight days the eggs are turned over, and, during all the handling, great care is taken to 
avoid sudden jars. The period of incubation is forty-two days - just twice as long as that required for the ordinary hen's egg. The young ostrich is about the size of a young pullet, when hatched, and has a brownish color, which gives him the appearance of an overgrown partridge. Not until they are half-grown do the male birds begin to differ in color from the females.

The young chicks are fed upon bran, corn-meal and green leaves, and grow rapidly. In six weeks they are as large as turkeys, and at three months they
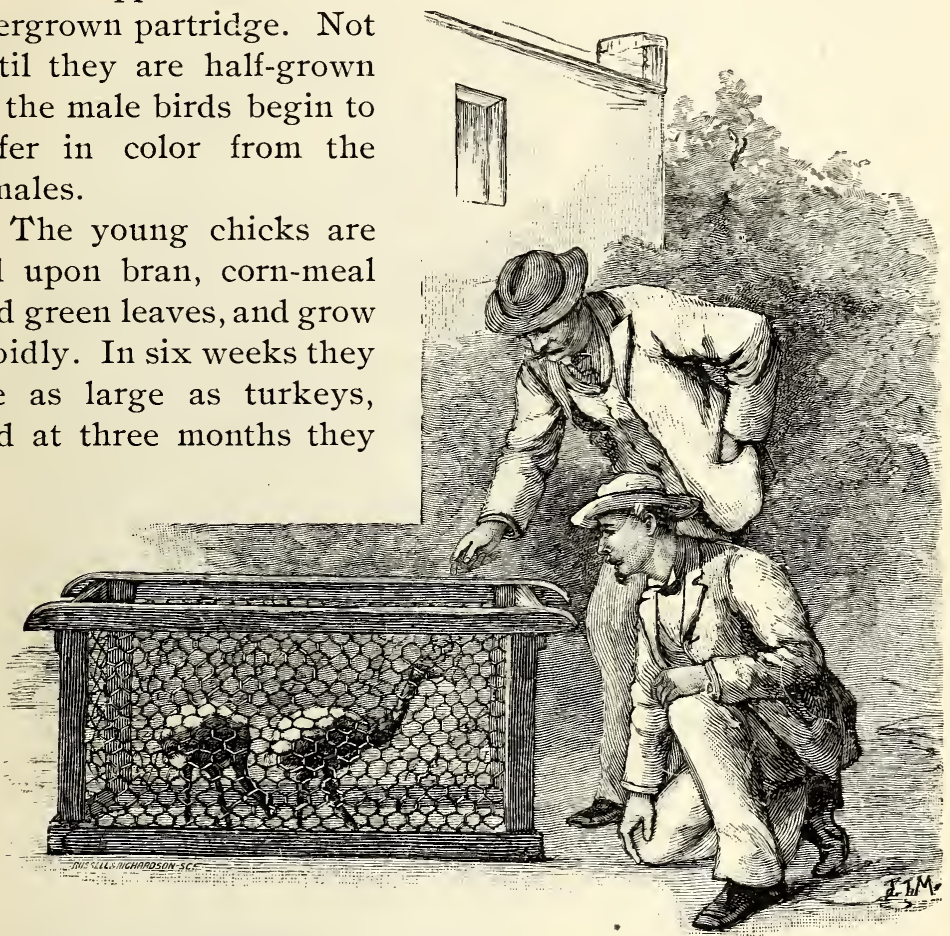

Ostrich-Farming in South America.

are four feet in height. The first ostriches brought from Cape Town to South America were sold for prices which would seem excessive if the profits of the business were not considered. Twelve hundred and even sixteen hundred dollars were paid for one pair of birds. The freight charge alone, upon forty ostriches imported by Mr. Sapello from Cape 
Town, was nearly four thousand dollars. The usual price now is about three hundred dollars for a single pair of ostriches raised in South America. The importation from Cape Town has practically ceased, since the birds do not lose by being bred in America, but rather gain in the quality of the plumage. A pair of half-grown ostriches, six months to a year old, are worth about one hundred and fifty dollars. The birds are first plucked at nine or ten months, and thereafter every six months. Plumes taken from the living ostrich are finest.

To obtain them, the bird is imprisoned in a kind of cage a small box-stall, on wheels, with a door at each end.

Into this the ostrich is driven and the door is fastened. Portions of the sides of the stall are ar-

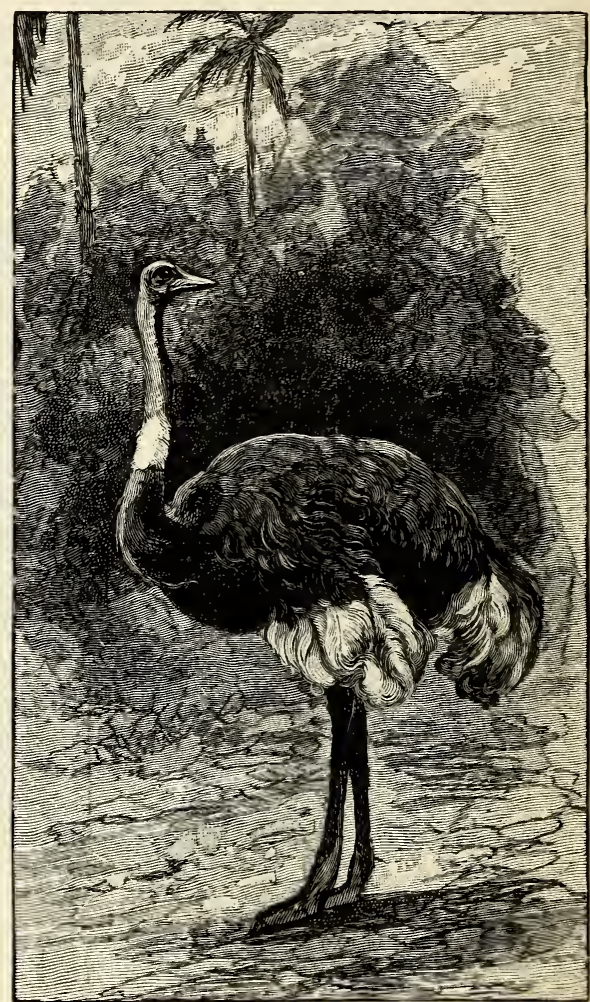

A Full-Grown Ostrich. ranged to let down on hinges, and through the openings thus made the plucking and cutting of the feathers is done. This caution is necessary in order to escape the powerful feet of the bird, for though the ostrich is not vicious, it is dangerous in close 
quarters. A blow from the wing of a full-grown ostrich has not infrequently been known to break a man's arm or leg. The limited intelligence of the bird is taken full advantage of in its management.

The smaller feathers are plucked. The plumes of the wings and the larger feathers are cut, leaving imbedded a stump of the feather some four inches in length. After a lapse of some two weeks or a month these stumps are pulled out from the wings with a pair of pincers. They have shrunk in this time to such an extent as to make their removal easy and painless. When the plucking is finished, the ostrich is released through the front door of the stall.

The yield can be counted upon almost to a certainty as to the number of feathers, but the price varies with the quality. The South American plumes are considered in London and Paris equal to those of South Africa, if not superior to them.

Two dozen large plumes are plucked or cut from each wing. Those cut from the male bird are pure white, except two, which are partly white and partly black. The long plumes cut from the wings of the female are white and gray. In addition to the long plumes from the wings of the male, there are about three ounces of smaller black feathers, and, from either male or female, about forty ounces of tail and breast-feathers. About three pounds of feathers are taken from each ostrich.

The first plucking, when the bird is only nine or ten months old, yields, at the present wholesale prices, five or six dollars' worth of feathers to each bird. The yield increases from year to year, until the ostrich has its full growth,about two and a half to three years, - when the clip from each is worth about forty dollars.

Henry H. BARRoli. 


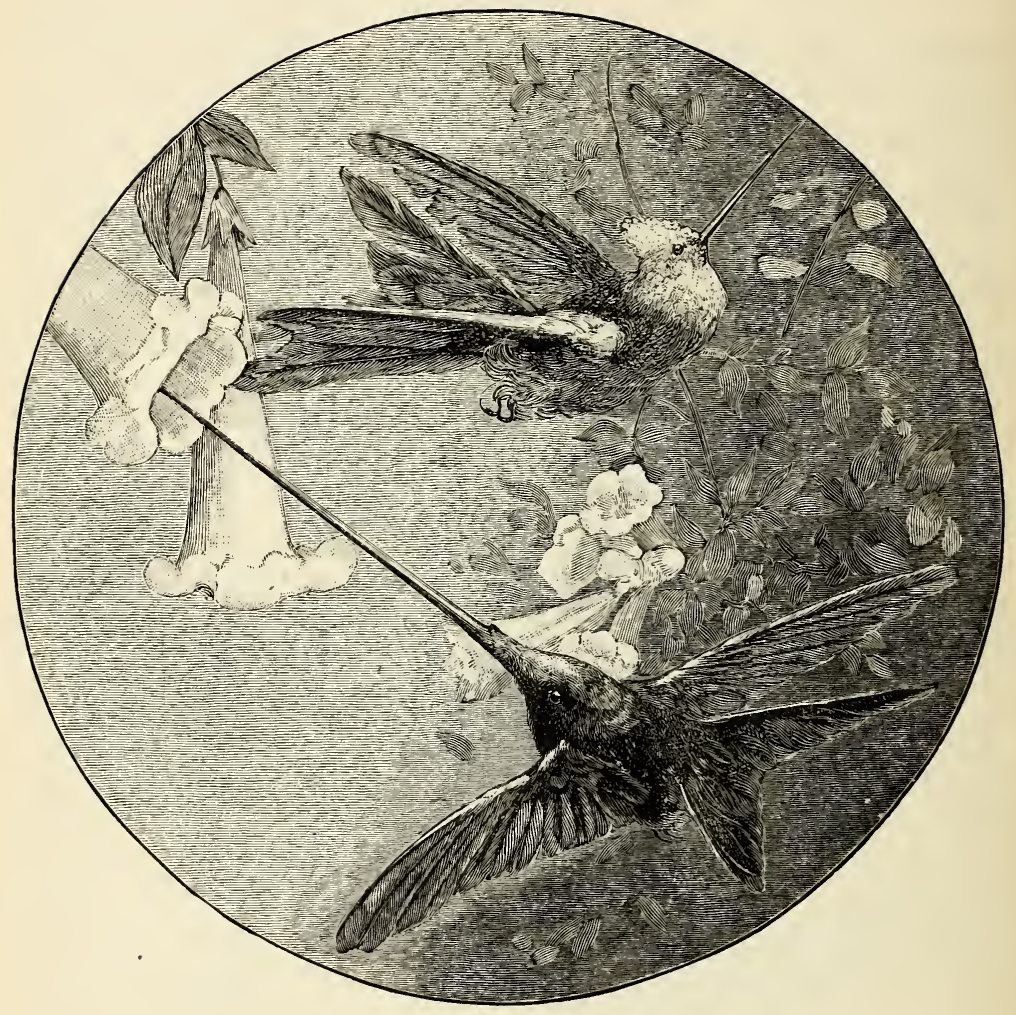




\section{A Widow's Mites.}

One bright day in June, as I delved in my little garden a loud humming close at hand caused me suddenly to look up. I was a trifle surprised to see, poised in mid-air some six feet from my head, an excited specimen of that dainty tropical visitant, the ruby-throated humming-bird.

Ten seconds later the bird was gone like a flash, but only to perch on a twig of the nearest tree, there to sit and watch my movements with evident concern.

Ignorant of birds and their habits though I was, the little creature's conduct seemed to me very peculiar, so I waited to see what would come next.

In less than five minutes the bird darted into the air, circled about twice or thrice, and then, dashing back to the tree, suddenly dropped, light as a feather and without preliminary perching after the usual manner of birds, full upon her nest.

There she sat in plain sight, as indeed she must have done for several days, though hitherto I had failed to see her. The nest was so tiny, so exactly the color of the bough that held it, and so shielded by overhanging leaves as to be very hard to find, even after one knew its position ; and yet it was, as I have said, in full sight all the time.

Luckily I have a neighbor who is deeply versed in birdlore; to him I hastened with the story of my discovery. An hour later we took advantage of the bird's temporary absence to inspect the nest.

We found that we could easily look from the top of a small step-ladder directly down upon the two tiny white eggs lying in their cup-shaped bed of downy vegetable fibre, and could examine closely the exquisite workmanship of the nest itself. It was saddled upon a drooping bough some ten feet 
from the ground. It was made of vegetable floss, soft as the finest wool, and was completely covered on the outside with bits of lichen to make it look like the mossy wood that supported it. How anxiously did we watch that tiny nest during the

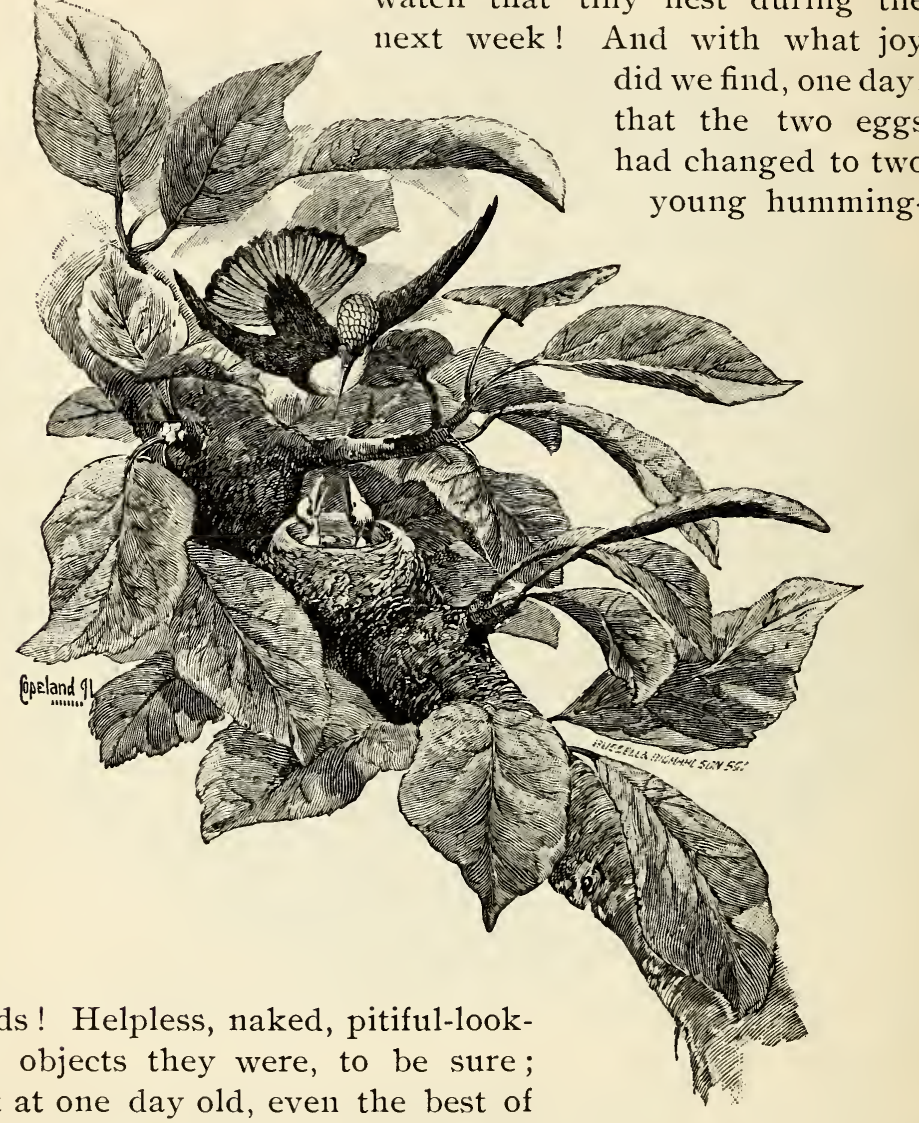

birds! Helpless, naked, pitiful-looking objects they were, to be sure; but at one day old, even the best of us are not remarkable for strength, grace or beauty. Looking at these helpless creatures, no bigger than bumblebees, their whole flabby bodies shaking with every beat of their little hearts, it seemed almost impossible 
that they should ever attain such brilliancy of plumage, such swiftness of motion, and such power of endurance as belong to adult humming-birds, and that in a few weeks.

But if we wondered at the generally wretched appearance of the newly-hatched humming-birds, owe wondered still more, and our wonder was mixed with great admiration, when we saw them survive the process of feeding.

Doubtless this process is just the one best adapted to the condition of young humming-birds; but to the human spectator it appears nothing less than cruel and dangerous. Imagine a human mother feeding her baby by thrusting down its throat a tube, say a yard long and two inches in diameter, placing the food in the upper end of this tube, and then violently churning the tube up and down so as to settle the food to the infant's stomach! The child would be dead before his meal was finished.

Yet all this would be not a whit worse than the process of feeding young humming-birds appears to be. The motherbird inserts her bill in the open mouth of her hungry offspring, and pushes it down as far as possible. Then follow, in rapid succession, a series of apparently very violent rammings and shakings, as the partially-digested food is raised from the stomach of the old bird and forced into that of the young one.

The first time that I saw this operation I felt sure that the poor little things would be corpses by the time it was ended; and many a time, as the mother's sharp bill was thrust with great haste and apparent force down the gaping throat of the helpless fledgling, I almost held my breath for fear it would go entirely through the little, soft body, and pin the wretched creature firmly to the nest.

No doubt this performance, notwithstanding its apparent cruelty, serves a good purpose in exercising the muscles of the young bird as well as aiding in the digestion of its food.

Thanks to the constant care of their hard-working mother, the helpless, naked, awkward little "hummers" gradually 
increased in size and strength, raised a crop of stubbly plumage, and began to look something like birds. Meantime, all accessible accounts of young humming-birds were carefully read, and found to require that the birds should leave the nest at the age of seven days. Now, from the very first it was plain that our birdlings had no intention of leaving home so early in life.

When they were a week old, and should have been, according to the books, spreading their wings for flight, they were still practically helpless, and their original nakedness was not yet decently covered by their crop of pinfeathers.

Their bills were, at this time, not longer than that of a sparrow, but much sharper and more slender. At two weeks of age the little fellows, though neither fully grown nor fully fledged, had yet acquired a noticeable likeness to their mother; but their plumage was less brilliant and their bills much shorter.

About this time one of the little birds began to pay strict attention to his health, taking exercise regularly after each meal, by standing up in the nest and vibrating his wings for perhaps ten or fifteen seconds. As he was fed about once an hour on the average, it followed that he got a good deal of exercise in the course of a day.

For several days longer affairs went on with little change except that the young birds grew noticeably larger and more uneasy, one of them surpassing the other in both respects. So large and active was he, and apparently so strong, that I should not have been surprised to see him fly away from the nest at any time after he was sixteen days old.

Yet still he lingered, and like his companion was fed by the mother, though he was occasionally seen to pick, from a neighboring leaf, an insect for himself.

The feeding by the mother-bird seemed now less dangerous than formerly, perhaps because the young, being larger and stronger, seemed better able to survive the violent treatment that always accompanied the operation. 
At last, when the birds were nineteen days old, the larger and more active one suddenly spread his wings in real earnest one fine morning, and flew out of the nest to a neighboring twig. He was not followed by his smaller and weaker sister till two days later.

For several days after this the two lingered about the tree in which they had been reared, or in its immediate vicinity, sometimes fed in the good old way by their watchful mother, sometimes feeding themselves on the insects that happened to be upon twigs and leaves near them.

During these days the mother occasionally fed them by putting food merely into their mouths, after the manner of birds generally, but more often the feeding was by the old method of regurgitation. She even shook one of them off his twig one day by the violence of her motions.

How long the birds remained in that neighborhood I cannot say, for a few days after the second one left the nest I was called from home, and did not return for three weeks. When I did return the birds were gone. However, I once afterward saw both the young birds and their mother in the old familiar tree. Then they flew away, and I have never seen them since.

E. F. Holden.

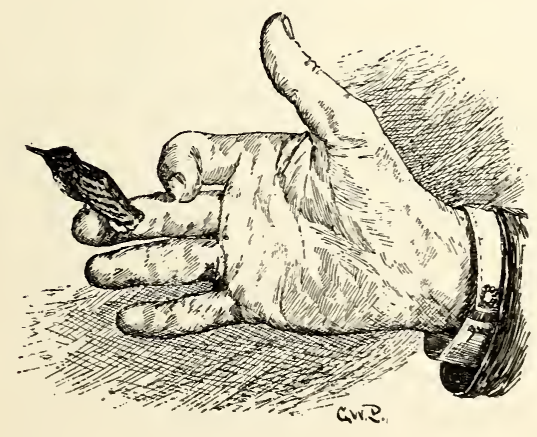




\section{Owls and their Uses.}

There is a popular belief that owls are exclusively birds of night and cannot see by day, or, if they see at all, that their vision is extremely limited. "As stupid as an owl!" is the common saying; but doubtless the

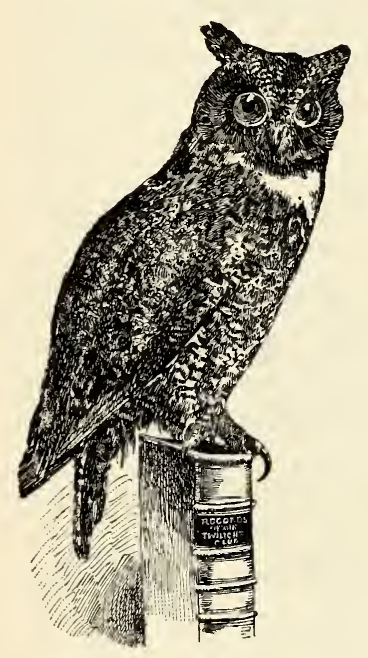

Fig. 1. phrase refers rather to feebleness of vision in open daylight than to any supposed mental deficiency.

In truth, owls are not stupid, nor are they by any means blind by day. Even ornithologists have, I think, erred in assuming that most owls are exclusively nocturnal, though it has long been known that one species, the Hawk Owl, hunts only by day. Probably at night its vision is as defective as that of a hawk.

I am inclined to believe that even the Great Horned, Barn and little Screech Owls, which are perhaps as nocturnal as any, are endowed with by no means keen vision in the dark, and that they do most of their hunting by twilight and by moon or bright starlight. True, it is possible to approach closely many of the owls in the daytime, as they sit dozing in their shady retreats, and not infrequently the smaller species may be caught in the hands. But the passiveness of the owls by day is the result more of sleepiness than of inability to see; and, once started in the daytime, and given a chance to rub open their drowsy eyes, so to speak, they are able to lead their would-be captors a lively chase. If any one has ever been aroused from a deep sleep to face 
the broad daylight suddenly, he will appreciate the feelings of the winking, blinking owl, and be surprised no longer that under such circumstances it has suffered the unjust imputation of stupidity.

But let us pass from general facts to particulars, and see what relation the owl tribe bears to man, especially to the farmer. It is high time the matter is understood; for if the

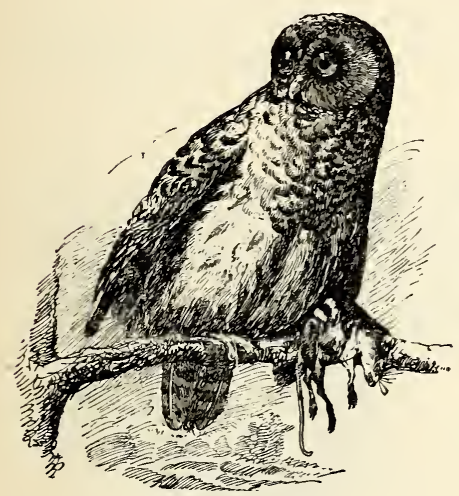

Fig. 2. owl be the farmer's friend, the farmer ought to know it, and bear a hand in the effort to stop the destruction of owls of all sorts for decorative purposes.

Of late there seems to be an abatement of the fashion, but in the last ten years many thousands of owls, from the Pigmy Owl, scarce a hand's breadth high, to the Great Horned Owl, with a spread of wing of three feet and more, have fallen victims to the fashionable craze. Let us consider the Great Horned Owl (Fig. I) first by reason of his size, his fine presence - for he is our finest species - and his economic importance.

He has shortcomings. The chief one is a liking for fowls and turkeys. But as he does not begin to hunt until it is dusk, and retires to the deep woods by early daylight, he seldom gets a chance at the farmer's fowls unless they roost in trees. Then he becomes a dangerous foe indeed, and one the farmer is justified in disposing of by any means.

However, when rabbits are plenty this owl prefers them; and in the far West, where the rabbit is extremely abundant and a most destructive foe to the crops, the Great Horned Owl does good service in warring upon them. Many thousands of pounds are annually expended in Australia in an 
attempt to destroy the rabbits - an attempt this owl woula gladly second if it were given a chance. The Barred Owl (Fig. 2) is not quite so large as the Great Horned, but though by no means as fine a species as the preceding, it is yet a notable bird. It is a good friend of the farmer, too, in the main, though its record with regard to chickens is not altogether a clean one. Still, it feeds mainly upon squirrels and mice.

Probably all the larger owls are cannibals, and do not disdain to eat one of their smaller brethren when opportunity

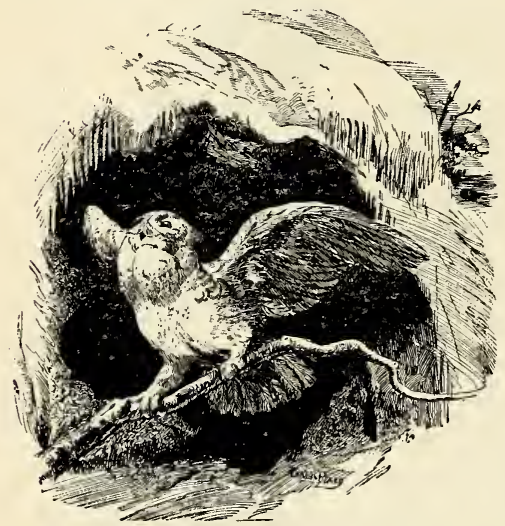

Fig. 3.

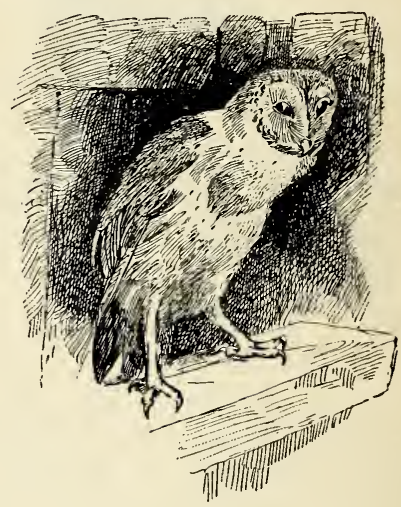

Fig. 4.

offers. The Barred Owl is no exception in this respect, and the remains of more than one Screech and Acadian Owlet have been found in the stomachs of their bigger relatives.

This species has often been tamed; and when taken from the nest it makes a gentle and interesting pet. Mr. Frank Bolles, in the Auk for April, I89o, tells a story of a pair he kept captive for a long time. It seems probable from one of his experiments that fish are eaten by this species when it can catch them. When some live perch were placed in the 
water-tank in the cage, both owls, though they were but three months old, and had never seen a fish before, exhibited great excitement, and immediately jumped into the water to seize their prey.

These pets, curiously enough, were fond of earthworms. At first they were afraid of snakes, but soon became curious about them, and subsequently killed and ate them with relish. So far as our farmers are concerned, the Snowy Owl (Fig. 3) is of less economic importance than som e others, since it is never present in the United States except in autumn and winter,

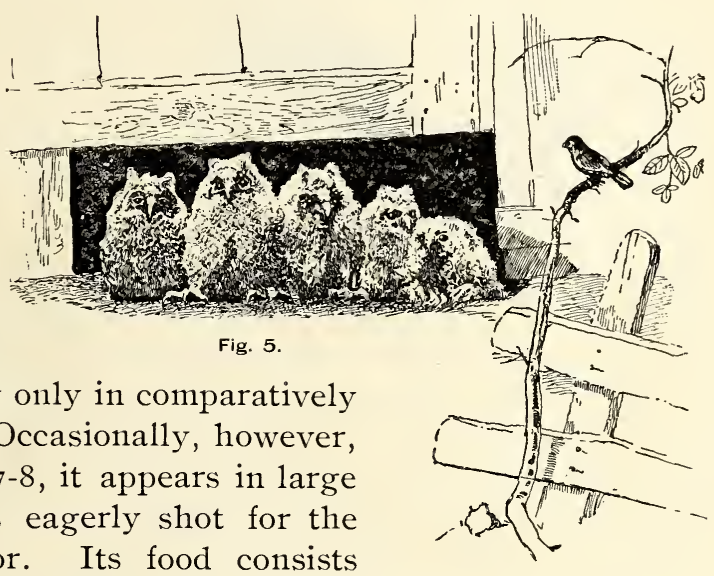
and then usually only in comparatively small numbers. Occasionally, however, as it did in $1877-8$, it appears in large numbers, and is eagerly shot for the cabinet or parlor. Its food consists chiefly of lemmings, hares and ptarmigans. When in the United States it also destroys many rats. Singularly enough, this owl is an expert fisher, and has often been seen on the margins of pools, waiting an opportunity to seize its finny prey. Very different from the preceding species both in appearance and habits is the Barn or "Monkey-faced Owl" (Fig. 4), as it is often not inaptly termed. While the Snowy Owl is a bird of the inclement north, the Barn Owl loves sunnier climes, and is found from about the latitude of the Middle States southward, not only through the United States but over almost all the world. Doubtless in early times the Barn Owl had to depend upon its own resources for a habitation, but it was quick to perceive the advantages of 
a co-partnership with man, and early learned to build its nest in odd nooks and crannies of barns, churches and monasteries.

This owl feeds nearly exclusively upon rodents, and especially mice, and does its hunting almost at the threshingfloor of the farmer. It is therefore a friend which should be

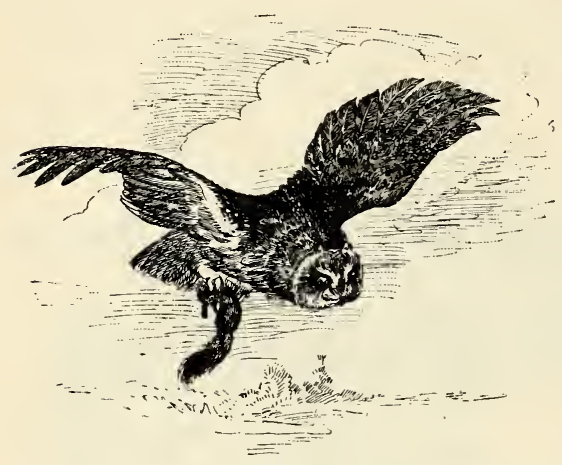

Fig. 6. peculiarly cared for by him and not left, as now, to be sacrificed to the passing whim of the moment.

The pouched gopher of California is peculiarly destructive to lawns, which it injures by tunnelling under the grass roots. It also does much damage in the garden. The number of these animals captured by the Barn Owl is simply enormous. The Southern planter also owes it a debt of gratitude from the persistent war it wages upon the cotton rat.

The Long-eared Owl (Fig. 5), as its name implies, has long ear-tufts, which give it a peculiarly wise appearance, and unfortunately render it a favorite ornament of the parlor and study. It is one of our most common owls, both East and West, and almost every dark pine thicket shelters a pair or two. It roosts in trees, and in them builds a rude nest of sticks and twigs. In the far West, I have started a dozen or more from a thicket of bushes a few yards in extent.

It is one of our most assiduous mouse-destroyers, and the presence of hundreds of pellets of mouse hair and bones usually marks the retreat of a pair of these birds. The downy young of all owls are curious-looking creatures, as may be seen from the accompanying illustration of a growing 
family of Long-eared Owls. Almost as soon as hatched, the nestlings will take food from the hand as readily as from the parent bird, and soon become remarkably tame and confiding.

The Short-eared Owl (Fig. 6) is of about the same size as the preceding, but the ear-tufts are inconspicuous.

Moreover, it is a bird of very different habits. It summers chiefly in the fur countries and the Northern prairie States, and winters far southward, becoming common in the United

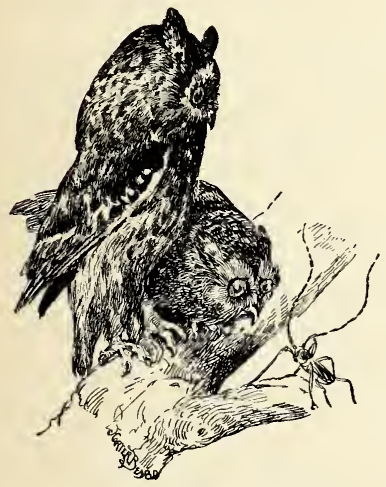

Fig. 7. States in the early fall. It is most at home in the marshes and open country, where it spends the hours of bright sunlight among the thick grass.

While it thus prefers to doze during the brightest hours, it can see remarkably well in the daytime, and, once wakened to a sense of danger, it is no easy matter to shoot it. Its food consists chiefly of mice and insects. Occasionally, doubtless, it destroys small birds, but its main subsistence is derived from animals that the farmer properly dreads; nor can he rid himself of them so easily and cheaply in any other way as by protecting the owls.

In the little Screech Owl (Fig. 7), whose length is less than ten inches, the farmer has another friend, and one whose value is not to be reckoned by its bulk. For this wiselooking tufted owlet is an inveterate foe to mice, and although he has been known to enter the farmer's domain and snatch a tender squab, or still more rarely a young chicken, he can plead that such misdeeds are performed but rarely, and only when family cares drive him to the necessity. For young owls are most voracious creatures, as one may learn who attempts to play nurse to a growing owl family.

Moreover, now that we know what a destructive pest 
is the English sparrow, it is well to note that "Scops" is very fond of this pestilent foreigner; and, from the habit of the sparrow of roosting about buildings, our owl is sometimes very successful in his patriotic attempts to reduce their numbers.

Very gentle and interesting pets Screech Owls make; and if taken from the nest when in the down, and well fed and petted, they may be released after a time with the certainty that they.will not wander far. Frequently they roost in the shrubbery near the house during the day, and at dusk fly to the window where they are accustomed to be fed.

They nest in the hollows of trees, and this is where they usually roost during the day. Not an old apple orchard in New England that has not a pair of these little owls snugly hidden away in the hollows of some gnarled tree. Other owls there are which are worthy of mention, did space permit.

Take them all in all, the owls must be considered friends to man. They are emphatically mice-eaters, and they supplement the work of the hawks by day by waging incessant warfare against man's enemies at a time when both hawks and men are resting.

H. W. HENSHAw.

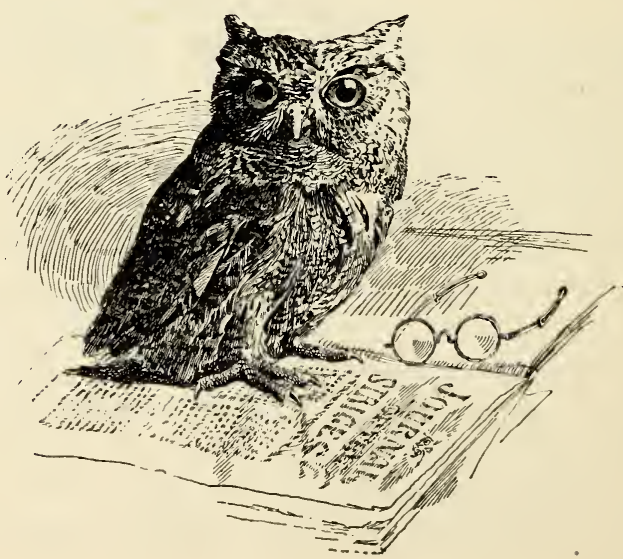




\section{THE COMPANION SERIES}

Preserves in permanent form some of the most valuable and interesting articles of the eminent authors who have written for The Youth's Companion. These Books are appropriate for Libraries, both private and public, and for use in Schools.

Each volume contains two hundred and fifty-six pages, is illustrated by The Companion's best Artists, is bound in strong linen, and contains four volumes of The Companion Library described on the inside cover at the beginning of this book. The Series comprises the following volumes:

By Land and Sea. A Book of Travel and Research.

Containing The Companion Library Nos. 2, 3, 4 and 5 .

Talks About Animals. A Book of Natural History.

Containing The Companion Library Nos. 6, 7, 8 and 9.

Our Country: West. The Newer Portions of the United States. Containing The Companion Library Nos. Io, II, I2 and 13 .

Our Country : East. The Earliest-Settled Regions of America. Containing The Companion Library Nos. $14,15,16$ and 17.

Price 50 Cents, Sent Prepaid.

PERRY MASON \& COMPANY, Publishers, 20I Columbus Avenue. BOSTON, MASS. 


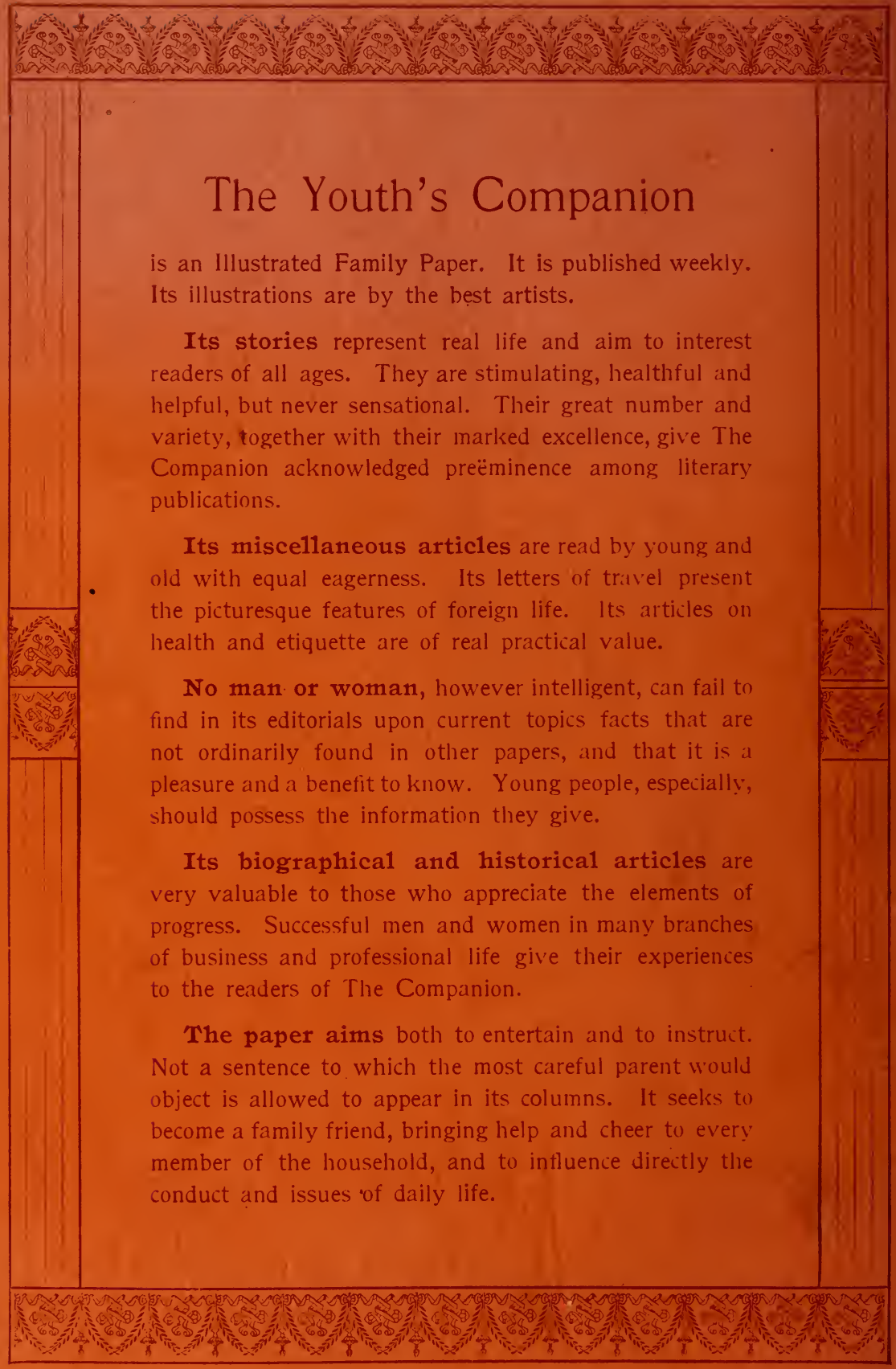

